\title{
State-Owned Firms and Private Debt
}

\author{
Pierre M. Picard*and Ridwan D. Rusli ${ }^{\dagger \ddagger}$
}

4 September 2017

\begin{abstract}
We study the role of private debt financing in reducing government transfers and information costs in a state-owned firm. We show that debt contracts allow the government to reduce socially costly subsidies by letting underperforming state-owned firms default. When the firm has private information, the government uses debt to reduce the firm's information rents. The option of default and privatize allows the government to stop subsidizing the firm. We identify the conditions under which information costs outweigh privatization costs and a positive debt level benefits governments.
\end{abstract}

Keywords: State-owned firms, privatization, debt, information asymmetry. JEL classification: L32, L33, H54.

${ }^{*}$ CREA, University of Luxembourg, Luxembourg, and CORE, Université Catholique de Louvain, Belgium. Email: pierre.picard@uni.lu.

${ }^{\dagger}$ CREA, University of Luxembourg, Luxembourg, and Economic Growth Centre, Nanyang Technological University, Singapore. Email: ridwan.d.rusli@gmail.com

${ }^{\ddagger}$ We are grateful to the editor and two anonymous referees for their interesting suggestions. We thank Lionel Jeusette and Deborah Schwartz for their research help. We are grateful to E. Auriol, A. Estache, A. Irmen and B. Zou for valuable comments. We thank Q. David, A. Gautier, P. Legros, D. Martimort and T. Valila as well as participants at ANR-Toulouse School of Economics, Public Economic Theory, CREA, University of Luxembourg, OxCarre, University of Oxford, University of California, Irvine, ECORE seminar at Katholiek University of Leuven, and Nanyang Technological University, for valuable inputs. All errors are ours. 


\section{Introduction}

In most developed and less developed countries, a non-negligible set of enterprises produce and sell goods or services with partial or full public financing, and under the control of a variety of governmental institutions. The US hosts government-sponsored corporations, federally owned corporations, quasi-governmental agencies in which governmental involvement is formalized (e.g. United States Postal Service, Tenessee Valley Authority). More than one thousand public hospitals are funded and controlled by state and local governments. Canada hosts para-public organizations like Universities and Hydro-Québec. France has its 'public establishments for industrial and commercial purpose' (EPIC) that manage metro and train infrastructures, opera, etc. Less transparent are some for-profit firms that nevertheless remain under the government's control. For instance, Amtrack has all 'preferred stocks' owned by the US Department of Transport and its CEO appointed by US Congress. In China and across the emerging world, many government-linked corporations are effectively controlled by their governments, even though they are listed in the stock markets and financed with private equity and debt.

State-owned firms that are financed, owned and controlled by the government are of major economic importance in many countries. While such firms contributed between 6-8\% of total GDP across countries worldwide in the late nineties, public interventions in the last decade have led governments to own approximately one fifth of global stock market capitalization (Megginson and Netter, 2001). A particular feature of state-owned or state-controlled firms is that they hold significant levels of debt in the form of loans and bonds to the private sector, which reduce government equity injections. State-owned firms usually incur debt levels higher than a third of their assets and are responsible for the issuance of many bonds worldwide. D'Souza and Megginson (1999) and Megginson et al. (1994) observe that state-owned firms' average debt-to-asset ratio range from $29 \%$ to $66 \%$, and that these ratios decreased after privatization. Borisova et al. (2012) describe no less than a thousand bonds issued by 215 listed state-owned firms across 43 countries in the last decade.

Debt leverage has become a concern for many governments and regulators. For example, the recent increase of debt leverage amongst public and private firms operating in regulated markets has motivated Ofwat, the UK water regulator, to introduce restrictions on companies operating with high debt levels (Correia da Silva et al., 2006; NAO, 2015). Similarly, the high leverage of procurement projects has increased the probability of financial distress and hence the frequency of renegotiation and recapitalization of Public-Private-Partnership contracts (Engel, Fischer \& Galetovic, 2010; Klein, 2012; Moore, Straub \& Dieter, 2014; Yescombe, 2011). 
The use of external debt by state-owned companies is striking for two reasons. On the one hand, governments generally access credit markets at better conditions than private agents. Because governments hold diversified portfolios of public projects, have recourse to taxation and face no bankruptcy risk, government bonds are considered as risk free and offer the lowest interest rates in most modern economies. As a consequence, public projects should be internally funded from the Treasury rather than externally with private creditors. On the other hand, the use of external debt contracts introduces the possibility of bankruptcy when state-owned firms are unable to meet their debt obligations. The government must then face the difficult decision of whether to refinance and bail-out state-owned firms, or to let them default and relinquish its control to private creditors.

A number of state-owned firms have indeed defaulted in the past and are still undergoing default procedures today. Creditors acquired (temporary) control of defaulting firms during the Asian crisis in the late 1990s. Many European public airline companies went bankrupt and/or were privatized in the past decades. Post companies like the UK Royal Mail are set in the process of privatization because their debts became a subject of intense political concern. In China, thousands of smaller Chinese central and regional state-owned companies have gone bankrupt over the years. Between 1975 and 2008, many financially distressed public hospitals in the US were unable to service their debts because of insufficient revenues resulting from excess capacity and increasing number of uninsured patients. Due to deteriorating public finances, many local governments refused to inject new funds and decided to privatize them (Ramamonjiarivelo, 2012, Ramamonjiarivelo et al., 2014).

Such cases of default and subsequent privatization of state-owned firms necessitate governments' commitment to -immediately or eventually- stop subsidizing the firm and face the risk of operational disruption and employees' and citizens' discontent. ${ }^{1}$ These examples take place under crisis conditions and in complex multi-year processes, often involving interim subsidies. Nevertheless, they highlight the fact that debt contracts may trigger governments' disinvestment in non-performing state-owned firms. In many instances, bankruptcy is not a necessary step for privatization. Numerous money-losing state-owned enterprises have placed themselves under pressure of their creditors before filing for bankruptcy. The have been privatized and sold to consortia of private investors that often included former creditors. Hence, the broader question that we explore in this article is whether the debt policy and the subsequent pressure from creditors can be used by governments as instruments to discipline state-owned firms' managements.

The objective of this article is to highlight the role of debt leverage when state-owned firms

\footnotetext{
${ }^{1}$ In this article we define liquidation as the government's act of defaulting and subsequently privatizing the state-owned firm to private creditors or investors.
} 
benefit from information advantages. We show that the government has incentives to induce the state-owned firms to take a debt contract with private creditors because the possibility of not bailing out the firm reduces information rents. ${ }^{2}$

To highlight this mechanism, we revisit the natural monopoly regulation set-up with adverse selection presented in Baron and Myerson (1982) and Laffont and Tirole (1993). A utilitarian and benevolent government monitors a state-owned firm operating in a natural monopoly market, such as transport, water, energy, waste, and health. ${ }^{3}$ The government faces an information asymmetry because the firm's management has private knowledge about the firm's cost (or demand parameter). The government faces a budget constraint that is summarized by its 'shadow' cost of public funds as discussed at length in Laffont and Tirole (1993). ${ }^{4}$ It maximizes a welfare objective that mixes the surplus to consumer, producer and creditors with the social cost of public transfers. The government offers incentive contracts to the state-owned firm's managers to reveal their private information at the cost of leaving rents to those managers. When the state-owned firm asks to be refunded, the government can either subsidize or reinject equity in the firms' operations, or let the firm default and thereby relinquish its ownership to the creditors. ${ }^{5}$ Ex-ante, the information rent increases with the range of the costs under which the state-owned firm operates. The government therefore has an incentive to reduce this range by defaulting the firms that report too high cost. This is the reason why debt can be used to diminish the extent of information rents. However, by doing this, the government foregoes information about true performance of defaulted firms. Defaulting may then also harm consumers as creditors have incentives to set too high prices. ${ }^{6}$

In this article, we show that the cost realization above which the government decides to default depends on the balance between information rents and allocative inefficiency after the change of

\footnotetext{
${ }^{2}$ Default provisions of typical loan agreements and bond prospectuses often exclude government guarantee clauses; they thus convey an implicit no-bailout commitment.

${ }^{3}$ Many state-owned companies are local natural monopolies like in water supply in poor countries and hospital care in sparsely populated rural America (Auriol and Blanc, 2009, Alexander et al., 1996, Langabeer, 2006). Before 2002, EU national airlines could benefit from an artificial monopoly position under countries' air transport bilateral agreements. Our analysis of monopoly can be generalized to oligopolistic markets as in Auriol and Laffont (1992) and Auriol and Picard (2008).

${ }^{4}$ As in Laffont and Tirole (1993), our model assumes that the shadow cost of public funds summarizes the tightness of the government budget constraint, whereby larger shadow costs indicate tighter budget constraints and increased opportunity cost of public funds.

${ }^{5}$ Creditors may in turn on-sell these defaulted firms to other private investors.

${ }^{6}$ Our base model assumes that government does not, but creditors do observe costs and prefer to set monopoly price following default and privatization. In the Appendix, we examine the case of price cap regulation post privatization to mitigate the allocative inefficiency.
} 
ownership. $^{7}$ The government prefers to inject equity from the Treasury and set the debt to zero when it faces low enough shadow costs of public funding. In this case, the information rent mainly consists of a redistribution mechanism from taxpayers to the state-owned firms, which has no social cost but makes debt an uninteresting instrument. This phenomenon may explain why most of the federally-, state- or city-owned firms in the developed economies borrow directly from their own Treasury and therefore use the public funding capabilities for their investments. In contrast, the government prefers to have the firm borrow from the private sector in many other situations. Debt is used for large enough shadow cost of public funds, such as it can be seen in developing countries. The social cost of information rents is then larger, which entices the government to use higher debt levels. The existence of social cost of public funds then becomes a key factor of leverage and privatization under asymmetric information. Other things equal, indebted state-owned firms should then be found more often in developing countries with strong financial constraints.

Literature The contribution of the paper is to explain how asymmetric information affects the choice of debt leverage in state-owned firms or in private firms lead by the government interests. It therefore inserts in the abundant literature on the benefits and costs of state and private ownership. ${ }^{8}$ The paper closely follows Laffont and Tirole's (1993) framework with asymmetric information between government and firms and with social cost of public funding. Our discussion focuses on natural monopoly markets owned and operated by a government that is uninformed and financially constrained. ${ }^{9}$ The paper adds on Auriol and Picard $(2008,2009)$ by introducing debt leverage as an instrument that help alleviating information rents by excluding weaker firms from the government's equity injections. ${ }^{10}$ The article also presents a new disciplining effect of debt contracts on better informed managers of public firms. It therefore complements the corporate finance literature on the role of debt as tool to alleviate moral hazard issues (e.g. Dewatripont and Tirole, 1994). ${ }^{11}$ In contrast with Gale and Hellwig (1985), information transmission at the

\footnotetext{
${ }^{7}$ The threshold cost level that we derive resembles that of Auriol and Picard (2009). In their study of outsourcing contracts the government mitigates the social cost of initial investments by contracting with a monopolist private operator and offering ex-post contracts only to private operators with costs below a welfare optimal threshold.

${ }^{8}$ See e.g. Laffont and Tirole (1993), Laffont (2005), Megginson and Netter (2001) and Chang (2007).

${ }^{9}$ Auriol and Picard (2008) discuss privatization in the context of oligopollies.

${ }^{10}$ Exclusion and participation constraints in principal agent models have been studied by Jullien (2000) and also applied by Calzolari and Scarpa (2009) to the study of regulation of exporting monopolies.

${ }^{11}$ For Dewatripont and Tirole (1994), Tirole (2005) and Myers (2001) debt mitigates moral hazard issues. Short term debt helps commit managers to making decisions that are better aligned with the objectives of firm owners, creditors and investors. For Leite (2001) short term debt allow investors to seize control of the firm in low profit states, which disciplines the manager.
} 
liquidation stage is here assumed to have no cost because we study the welfare trade-off between information advantages before and after default. ${ }^{12}$ The paper also discusses a form of interaction between debt financing and product market behavior in the presence of state-owned firms. While higher leverages entice private firms to produce less in oligopolistic markets (Faure-Grimaud, 2000; Povel and Raith, 2004), they here have no effect on the production of the state-owned firms that are not defaulted. Leveraging however leads to more privatization and thus higher prices and lower aggregate output.

The article differs from a series of research contributions about the interaction between regulated firms and debt levels. In this literature, debt leverage is used by private owners to alleviate the hold-up problem created by opportunistic regulators in the context of exogenous bankruptcy "distress" costs (Dasgupta Nanda 1993; Spiegel and Spulber, 1994). In the same line of research, Cambini and Spiegel (2015) examine the debt and capital structure of the regulated firms that make investments under cost uncertainty and must produce under rigid regulated prices. By contrast, the present paper only considers state-owned firms, does not encompass any opportunistic behaviours and distress costs and does not discuss the sizes of investments. Also, prices are here determined ex-post according to ex-post information reports.

Finally, the article relates to the literature on Public-Private-Partnerships (PPP). A few papers address the question of debt leverages in PPPs. ${ }^{13}$ de Bettignies and Ross (2009) study the choices of state-owned firms' debt and default in an asymmetric information setting like ours, but they root such choices in government officials' interests for re-election. Iossa and Martimort (2015) discuss the impact of outside finance on the risk sharing structure of PPP contracts in the context of moral hazard. They show that outside finance improves risk sharing between governments and PPPs managers when creditors have more information on PPP's actions than governments. They do not offer explanation for high debt leverages. Menezes and Ryan (2015) show how PPP consortia take debts in order to hold up government and tax payers. Debts insure them with more profit in low demand states because it forces governments to renegotiate concession contracts. This short

\footnotetext{
${ }^{12}$ Appendix $\mathrm{C}$ extends the model to bankruptcy and auditing costs. While these factors lower the maximum feasible debt level, our overall results remain unchanged.

${ }^{13}$ An exception is Engel et al. (2013). In general, the literature on PPP discusses the costs and benefits of task delegation of public services to private firms and considers the complementarity in construction and operational tasks as the main reason for delegation to private or semi-public consortia. Many authors have focused on questions of renegotiation, design, moral hazard and assessment of PPPs (e.g. Dewatripont and Legros, 2005, Guasch et al., 2006, Iossa et al., 2007, Estache et al., 2008 and 2009, Engel et al., 2013, Estache and Saussier 2014). With the recent exception of Iossa and Martimort (2012), this literature does not discuss the issue of information acquisition (adverse selection) that is the basis of the earlier literature on regulation theory that we build upon (Baron and Myerson, 1982, Laffont and Tirole, 1993).
} 
literature does finally not study the role of social costs of public funds as it is done in this paper.

The article is organized as follows. To make precise our research object, Section 2 provides case studies about state-owned firms and debt leverage. Section 3 presents our model while Section 4 discusses the output, price and default decisions under asymmetric information. Section 5 describes the choice of the optimal debt level. Section 6 discusses our main results. Section 7 concludes and identifies areas for further research. Proofs and extensions are respectively relegated to the Appendices A, B and C.

\section{Case studies}

Before presenting our analysis, it is important to document important features about state-owned firms. The first feature is about their financial independence and discretion in making capital structure decisions. In this paper we argue that by determining the amount of state equity injections or subsidies, the government implicitly determines the firm's debt level. The role of government in debt decisions is further amplified by the the state's influence in the choice of board and management members and in the legal articles of state-owned companies. Furthermore, the existence of financial transfers from or to government in terms of dividends, equity injections and appropriations amplifies the state-owned firm's dependence. The second feature is that many state-owned firms issue debt and bonds without government guarantees. The existence of non-guaranteed debt makes private creditors the residual claimants of the firm when the latter is unable to pay interests and repay the borrowed capital. The role of government then becomes crucial as it can avoid subsidizing or injecting capital and let the firm default. The third feature relates to the use -or the threat of use- of the debt bankruptcy clauses or procedures by the creditors of state-owned firms. In this paper we derive and argue that the threat of bankruptcy lowers the state-owned firm's incentives to misreport their true performances.

Table 1 presents cases of state-owned firms in OECD countries with their financial structures and links to governmental institutions. The table includes the share of public ownership, share of government representatives in the board, equity, amounts of debt that are guaranteed and not guaranteed by governments, amount of subsidies or equity injections and possible dividend payments or taxes to the government. Those examples show a strong financial and decision making dependence in the railway, energy and post mail sectors. They also show evidence of non-guaranteed debt. We now review some of those examples in more details, begining with railway network markets. For the sake of readility, most source references are relegated to Appendix A.

The French Société nationale des chemins de fer français (SNCF) is wholy owned by the French 
government and has only government's representatives in the board. The firm's dependence is also reflected in the "performance contract" that was agreed between the government and the Réseau Ferré Français (RRF), the network infrastructure component of the SNCF holding between 1997 and 2014. Co-signed by the French President and four competent French Ministers for the period of 2009-2012 and renewed until 2014, this contract specified the relationship between prices and costs and the part of the debt that should be funded by firm's revenues (60\%). Its board included members nominated by the Ministers and Presidents of French Regions, etc. The ongoing management of debt in the credit markets was subject to a risk/return coefficient given by this board. SNCF receives substantial investment subsidies from the central government and appropriations for its services to regional collectivities. It pays regular dividends to the State although, in 2014, the government declared not to require dividends to help the firm reducing its deficit. Recently, the French general accountability office (Cour des Comptes) expressed concerns about the firm's high dividends and endebtedness. The debt level is largely above the amount of equity of the firm and other firms in the sector. The existence of a debt guarantee by the government is not written in the law governing semi-public firms (EPIC) and therefore SNCF. The current firm's CEO has claimed that the debt has no government guarantee although the EU Court of Justice has recently judged that the public status of EPIC should give unlimited guarantee. In the next years, the SNCF will probably clarify its status by changing to the one of a private company (as it has been done for EDF, see below). More generally, at the same time as highly indebted EU governments want to write the public firms' debt off their national debt, they are increasingly forced by EU institutions to change public firms' status for doing so. As a consequence, one shall be expect that EU governments reduce their commitments of debt guarantees in a credible way. 


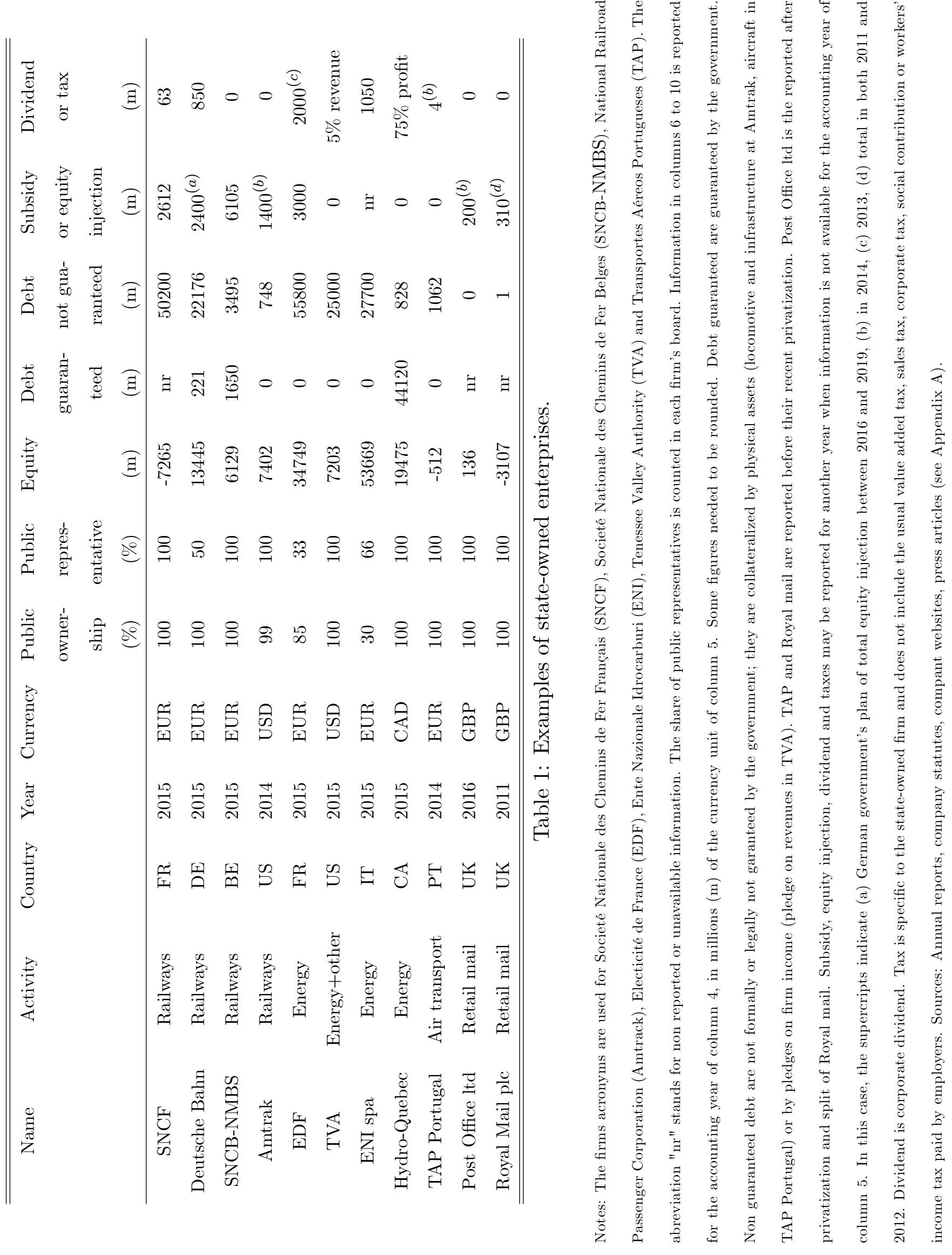


Similarly, the Société nationale des chemins de fer belge- Nationale Maatschappij der Belgische Spoorwegen (SNCB-NMBS) is fully owned by the state and has its board members nominated by the government. Similar to the SNCF, the railway infrastructure is operated as a "public autonomous enterprise" and subject to a detailed management contract set in a decree law. The latter specifies the nominal debt level and growth rate, as well as the appropriations from the government for investments (equity injection) and for non-commercial operations in favor of commuters, cross-border transit, public services, etc. (subsidies). SNCB-NMBS holds an amount of debt that is close its equity. The firm emits Euro Non-Call Notes, whose prospectuses reveal no guarantee by the state or public institutions. The firm is also subject to privatization pressures. As a case in point, in 2014, its CEO expressed his concern about the necessity of privatization if the firm could not get its debt under control.

Deutsche Bahn shares the same features. Its ownership structure, board and/or management is strongly controled by the government while it receives many appropriations and equity injections from its governments. In particular, the German federal government plans to inject 2400 million Euros of equity over the next four years and will reduce its dividend requirement from 950 to 600 millions in 2016. It holds an amount of debt that amounts to almost twice its equity. Only one percent of its debt is guaranteed by the federal government: this is for its borrowing from Eurofima, a international borrowing consortium requiring explicit government guarantees. In the 2000s Deutsche Bahn was subject to ongoing privatization discussions because of its recurrent needs for equity injection. However, its introduction in the stock market has been postponed due to 2008 financial crisis.

In the US, the rail transport company, Amtrak, is managed by a board of 9 members appointed by the President of the US and confirmed by its Senate. Founded in 1971, the firm was set up as a federally chartered corporation that can receive taxpayer funding and operate intercity passenger trains. As of 2015, Amtrak was capitalized with about 7 billions USD in equity mainly held by federal and state governments. It receives about 1 billion USD appropriations for its operations from the federal and state governments annually. It has a debt level of less than 1 billion USD. The loans and bonds are backed by Amtrak assets such as locomotives or by pledges in the equipement or infrastructure the money is used for. Amtrak takes Railroad Rehabilitation and Improvement Financing (RRIF) loans from the US Department of Transportation, which can but need not provide guarantees (to our knowledge, such guarantees are not formally stated). In addition, Amtrak issued commercial debts to private suppliers and clients and unsecured loans to foreign debtholders. Amtrak is at the heart of many controversies because it has never achieved self- 
sufficiency. In 1995 Amtrak was unable to continue to service its debts and was refunded by the Congress for 5 billion USD. The same problem occurred in 2013 at a time of US economic crisis where federal appropriations where cut and the Congress waited to vote for additional federal funding. In a quality control audit certified by Ernst \& Young, the Inspector General stated that "without the receipt of Federal Government funding, the Company will not be able to continue in its current form, and significant operating changes, restructurings, or bankruptcy might occur."14 Unsecured creditors, particularly the Export-Import Bank of Canada, had incentives to force to company to enter a Chapter 7 liquidation process and receive repayment for the equipment they have financed (e.g. for the Acelas, Viewliners and Superliners projects). In theory, the Congress could have granted cash and guarantee loans quickly, but it took many years to decide what to do. In the meantime Amtrak' assets could have been restructured, split and or sold.

In the energy sector, the state-owned firms presented in Table 1 have similar features: their ownership structures and boards are strongly controled by governments. By contrast, they generally offer cash revenues to governments in terms of dividends or special taxes. For instance, the French government holds a 85\% share of the capital of French national electricity company, Electricité de France (EDF). The board includes six members elected by the shareholders' assembly, six proposed by the employees, five proposed by the government and, a State representative who has veto power. In spite of the strong public influence, the firm is currently endowed with the legal status of a private company. This is because the 2004 liberalization of the EU electricity market forced the firm to drop its public firm status (EPIC), making clear that its debt is not guaranteed by public institutions. EDF generally pays good dividends and returns on equity, about 5\% in 2015 (see 2000/34749 from Table 1). That year, the firm increased its capital by 4000 million Euros, three quarter of which was equity injection by the French government. EDF holds a debt level of the same order of its equity. In practice, EDF emits Euro Non-Call Notes, whose prospectuses state no government guarantees.

In the US, the Tennessee Valley Authority (TVA) supplies electricity and natural resource management in Tennessee and parts of Mississippi (Kentucky, Alabama, Georgia, North Carolina and Virginia). It is a federally-owned corporation with a board of directors appointed and confirmed by the President of the US. Its overall goal is to remain profit-neutral and offer inexpensive energy. Yet, five percent of its gross revenues are collected for the states in which it operates. It is

\footnotetext{
${ }^{14}$ See Amtrak Office of Inspector General, Quality Control Review of the Independent Audit of Amtrak's Consolidated Financial Statements for Fiscal Years Ended 2013 and 2012. Report No. OIG-A-2015-003, January 13, 2015.
} 
not authorized to issue stock shares and does not receive any federal funding, which explains the absence of subsidy in Table 1 and the recourse to various debt instruments. TVA finances its investments and operations through the sale of TVA bonds, some of them with equity convertibility. However, the federal government does not explicitly guarantee any TVA bonds, meaning that if TVA was to default on any of its debt, the government is not obliged to repay the TVA's creditors or bondholders. Finally, discussions on privatization were introduced by the Obama adminitration in 2013. The huge debt is an issue as it is considered by some political bodies to be part of the national debt.

The Italian petroelum corporation, Ente Nazionale Idrocarburi (ENI), became a private company by Law Decree in 1992, the government selling $70 \%$ of its shares in the stock market mainly to international institutional investors. However, six out of the nine board members are nominated by the Italian Ministry of Economy and Finance that has de facto control over the firm through its bank Cassa Depositi e Prestiti. ENI holds bank loans and emits Euro notes (bonds), in which no government guarantees are stated. Talks of privatisation exist but are linked to the Italian debt. The reality however provides a mixed spectrum for the government debt guarantees. For instance, Hydro-Quebec, one of the largest world hydropower producer, has a debt that is larger than twice its equity and structured with bonds that are backed by the Quebec government. The firm is regularly subject to discussions about privatization to lower the Canadian province's public debt.

Table 1 also reports two state-owned firms before their privatization, which provides information about state-owned firms in debt crises. Before 2015, the TAP Portugal airline was fully owned and controled by Portuguese public authorities. It had negative equity and some 1062 million debt partly secured by its assets (aircrafts and other). In our research we have seen was no mention of explicit state guarantees. Because of EU regulations on state aids, the Portuguese government could not inject capital into the heavily-indebted and loss-making firm, leaving it on the brink of bankruptcy. The privatization of the Portuguese state-owned airline Tap Air was then conducted as part of the EU/IMF bailout to repay the company's outstanding debt. TAP Portugal was finally privatized in November 2015 when Portuguese government sold $61 \%$ of its shares. It nevertheless bought back 11\% of shares up in early 2016 to regain the majority control of the firm. Bankruptcy of European state-owned firms is perhaps a regular event in the air transport sector, which is subject to instability. In 2001, the Belgian government relinquished the stateowned airline company, Sabena, to its creditors when that the firm was unable to repay is debts. Around the same time, the government-owned Swissair company was handed over to a liquidator 
after being unable to make payments to creditors and UBS AG's refusal to extend its line of credit. The company was sold to Lufthansa a few years later. In 2008, the Italian government filed its national airline Alitalia for bankruptcy and later sold its shares in a privatization program.

Near-bankruptcy is also present in post mail services. Intense discussions about privatisation of UK Royal Mail company took place during the 2000s after several years of losses. A main reason was the lack of expertise in addition to lack of external financing and growing pension deficit.

Finally, the Chinese market that offer many stories about state-owned firms. The largest national oil, and telecommunication companies such as PetroChina, Sinopec, CNOOC, China Telecom and many others are listed on the Hong Kong and Chinese stock markets, and raise significant levels of unguaranteed loans and bonds from private lenders and investors, both domestically and internationally. These companies' strategic and funding decisions continue to be influenced by the Chinese government, as the Chairman and many senior directors and managers of these firms are either appointed by the government or have previously worked in the government policy-making and regulatory institutions. Many of those firms have faced difficulties and bankruptcy threats. This is the case of the state-owned Baoding Tianwei Group Company, that became the first official case of a Chinese state-owned firm bankruptcy. Active in electrical power transformers and other electrical equipments, it engaged in wind mill and solar panel manufacturing. However, market oversupply and operational issues led the company to losses so that it had to default on a bond interest payment. When banks required the firm to repay its bonds in 2015, the Chinese government decided to let the firm file for bankruptcy. ${ }^{15}$ Other thousands of smaller Chinese central and regional state-owned companies have gone bankrupt over the years. In the process many assets and firms have been reallocated to stronger firms, including to private operators (World Bank, 2001).

Those cases clarify the extent and the role of government in state-owned company funding. Debts are often directly or indirectly decided by government instances or representatives. They are also not systematically associated with government guarantees and their debt level have become a concern of bankruptcy threat in some instances. The following section describes a model in which the motivation for leveraging state-owned firms with non-guaranteed debt stems from the rents associated to their control.

\footnotetext{
${ }^{15}$ See Bloomberg News, April 22, 2015.
} 


\section{The model}

We consider a state-owned firm with a natural monopoly position and increasing returns to scale technology. As in Baron and Myerson (1982) and Laffont and Tirole (1993), the firm is owned by the government and incurs an up-front fixed investment cost $K$ that yields uncertain economic surplus and profit. The firm sells its output $Q$ to consumers who enjoy a gross surplus $S(Q)$, $S^{\prime}>0>S^{\prime \prime}$, and whose inverse demand function is given by $P(Q)=S^{\prime}(Q), P^{\prime}<0$. Their net surplus is given by $N(Q)=S(Q)-P(Q) Q$, with $N^{\prime}>0$. Production and sales yield an operational profit $\Pi(\beta, Q)$ that includes revenues minus production costs (exclusive of investment cost $K)$. The operational profit depends on the output and an uncertain performance parameter $\beta$. To conform with the regulation literature, we will say that this parameter is a cost parameter of the firm (although it can readily be interpreted as demand parameter). Its probability density and cumulative functions are given by $g(\beta)$ and $G(\beta)$ on the support $[\beta, \bar{\beta}]$. In this paper we need not be specific about this cost function and find it more instructive to focus the discussion on operational profits $\Pi(\beta, Q)$. We just assume that the cost parameter negatively affects the profit and the marginal profit so that $\Pi_{\beta}<0$ and $\Pi_{\beta Q}<0$ whereas we assume $\Pi_{Q Q}<0$ to guarantee concavity of profit. ${ }^{16}$ To ease the analysis, we assume that there always exists a positive production surplus after the investment is made and that production always reaches a finite level. That is, $\lim _{Q \rightarrow 0} \Pi(\bar{\beta}, Q)>0$ and $\lim _{Q \rightarrow \infty} \Pi(\beta, Q)<0 \forall \beta$. Once the investment is sunk, the economic surplus is equal to the sum of consumer net surplus and production surplus $N(Q)+\Pi(\beta, Q)$. We assume the latter to be a strictly concave function of $Q$ to guarantee an interior socially optimal solution.

We study three parties: (i) the national or local government as benevolent utilitarian planner or industry regulator, (ii) the manager of the state-owned firm, and (iii) a group of private creditors. For the sake of simplicity, we assume that all parties are risk neutral and have zero opportunity costs of time. They all know the value of the investment cost $K$. To focus on the issue of debt leverage, we suppose that the investment decision $K$ is given. The point is to set the appropriate debt-equity structure. The manager of the state-owned firm gets a utility $U$ from her position and has a reservation utility to work in the company, which we normalize to zero. Creditors raise their funds in capital market at zero interest rates and get a utility $C$ from the difference between the

\footnotetext{
${ }^{16}$ For instance, performance paramerer $\beta$ can be the firm's marginal cost so that the profit writes as $\Pi(\beta, Q)=$ $P(Q) Q-\beta Q$. Concavity conditions require that the demand function is not too convex: $P^{\prime \prime} Q+P^{\prime}<0$. By contrast, $\beta$ can be about demand so that profit is defined as $\Pi(\beta, Q)=P(\beta, Q) Q-c(Q)$ with $P(\beta, Q)=1-\beta-Q$. The same analysis and result apply.
} 


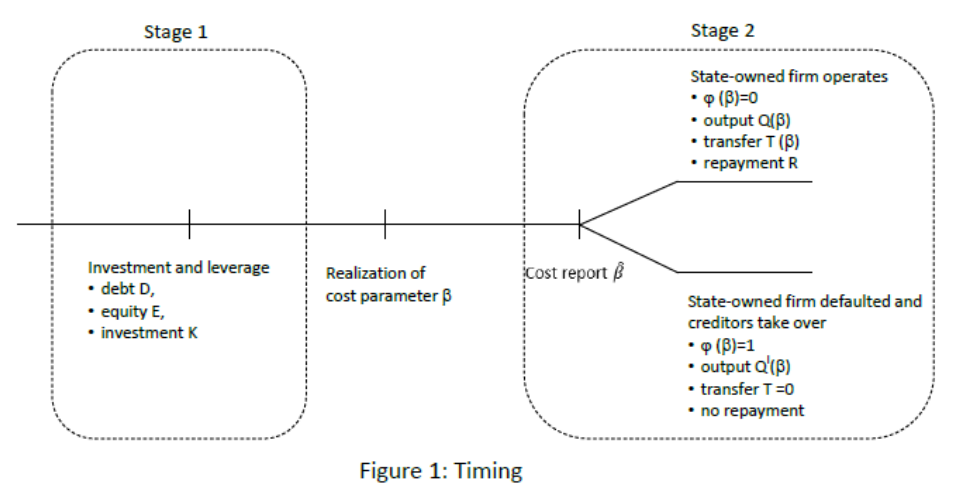

cash they lend and get repaid. (The assumptions of zero interest rates and zero opportunity costs of time are relaxed in Appendix C.) For simplicity and as presented in Table 1, the government is the sole equity owner. It is endowed with a benevolent, utilitarian objective that encompasses the surpluses of consumption, production, manager and creditors in addition to the social cost of transfers from the Treasury.

As in Laffont and Tirole (1993), the government's social cost of public funding is summarized by the shadow cost of public funds $\lambda>0$, which represents the deadweight cost of raising one dollar from tax payers. It measures the government's shadow value of raising public funds; the tougher its budget constraint, the higher $\lambda$. More precisely, any dollar spent by the government implies a social cost of $1+\lambda$ to the society. This social cost reflects the administrative cost of taxation and the economic inefficiencies in taxing labor, production and consumption (Auriol and Warlters, 2012). It is estimated to lie in a range about $\lambda=0.3$ in developed economies and in a range higher than $\lambda=0.9$ in least developed countries (World Bank, 1998). This parameter can become even higher for government under very strong financial constraints (e.g. under EU or IMF restructuring pressures). ${ }^{17}$ The shadow cost of public funds is a parameter of aggregate tax distortions. It allows us to concentrate on the micro-economic distortions in the product market and in the agency relationship between government and state-owned firms.

The model includes two stages depicted in Figure 1.

\footnotetext{
${ }^{17}$ The shadow cost of public funds actually measures the welfare impact of a marginal change in the government's total budget. Because the transfer to the state-owned firm is supposed to be marginal compared to the total budget, the shadow cost of public funds has the same value for positive and negative transfers (see Laffont and Tirole, 1993).
} 


\subsection{First stage}

In the first stage, the government supplies the amount of equity $E$ from its Treasury and the state-owned manager chooses the amount of debt $D$ from creditors. However, this amount of debt should balance the firm's assets and liabilities so that $E+D=K$. The balance between equity injection and debt reflects the internal versus external funding trade-off of the government. Given that the financing and investment transaction is observable and verifiable, the firm's manager can make no utility out of it. Her utility is given by $U_{1}=0$, where the subscript 1 refers to the first stage. On the other hand, the creditors raise the debt amount $D$ in capital markets and lend it to the firm. They make no utility out of the transaction in the first stage so that their utility is given by $C_{1}=0$. In compensation for their transaction, they are promised a debt repayment $R(R \geq D)$ from the state-owned firm in the second stage. The government considers the total welfare, $W_{1}=U_{1}+C_{1}-(1+\lambda) E$, which includes the manager and creditors' utilities and the social cost from making public transfers to the firms. This simplifies to

$$
W_{1}=-(1+\lambda) E
$$

To sum up, the first stage welfare is equal to the equity injection at the shadow cost of public funds.

At the end of first stage, the uncertainty in the cost parameter $\beta$ realizes. The government is not informed about the realization of this cost.

\subsection{Second stage}

In the second stage, the state-owned firm produces and sells its goods or services and must repay the promised repayment $R$ to the private creditors. If it cannot repay $R$, the firm however gets defaulted. As the main shareholder, the government relinquishes the firm to the private creditors and looses its control and cash-flow rights on the firm: the firm is privatized. ${ }^{1819}$ The government may however wish to give a transfer $T$ to the firm or receive $-T$ from it according to its balance between economic surplus and cost of public transfers. When $T>0$, the government subsidizes the firm or reinjects equity in the firm while it taxes the profits or gets the dividends when $T<0$. Subsidies typically are appropriations that complement the cost of public service as is the case for

\footnotetext{
${ }^{18}$ As in the literature following Spiegel and Spulber (1994), creditors become the residual claimants of the firm's profit.

${ }^{19}$ In the remainder of this article we use the terms 'liquidation' and 'privatization' interchangeably. Indeed, in practice, the assets of the firm can be liquidated to repay creditors and the control and cash-flow rights is transfered to a private investor who takes over the firm's operation.
} 
railways (e.g. USA, Belgium and France in Table 1). In EU, extreme cases of equity injections are "state aids for restructuring firms in difficulty" as foreseen by the EU Article 87(c)..$^{20}$

Formally, the government asks the state-owned firm's manager to report its cost $\widehat{\beta}$ and decides whether the firm is viable for production under state ownership or whether it should be defaulted and left to creditors. The government proposes the contract $\{Q(\widehat{\beta}), T(\widehat{\beta}), \varphi(\widehat{\beta})\}$ that specifies the output, transfer and default decision $\varphi \in\{0,1\}$ according to the manager's cost report $\widehat{\beta}$. On the one hand, if $\varphi(\widehat{\beta})=0$ the state-owned firm pays its debt, sells its goods or services at the price $P(Q(\widehat{\beta}))$, receives (or pays) the transfer $T(\widehat{\beta})$. The manager's utility sums up to the operational profit $\Pi(\beta, Q)$ minus debt repayment $R$ plus transfers $T$. The creditors get a utility equal to the firm's debt repayment $R$ minus their own repayment to the capital market $D$. On the other hand, the firm is defaulted if $\varphi(\widehat{\beta})=1$. The manager loses her job and has zero utility while creditors get the ownership of the firm and receive the rights to the operational profits of the firm, $\Pi(\beta, Q)$ and pay back $D$ to the capital market. To sum up, the state-owned firm manager's utility writes as:

$$
U_{2}=[\Pi(\beta, Q)-R+T](1-\varphi)
$$

where the subscript 2 refers to the second stage and where we dispense the variable with reported $\operatorname{cost} \widehat{\beta}$ for the sake of readability. The creditors have a utility is given by

$$
C_{2}=R(1-\varphi)+\Pi\left(\beta, Q^{l}\right) \varphi-D
$$

where $Q^{l}$ is the output that they can set after default since they then acquire the right to operate the firm. ${ }^{2122}$

The change of ownership has its drawbacks. It shifts the private information to the creditors who receive the control rights of the defaulted firm. This information asymmetry stems from the fact that creditors usually comprise a group of informed banks with adequate monitoring technology and incentives. ${ }^{23}$ To discuss this idea, we make the assumption that creditors are able to observe

\footnotetext{
${ }^{20}$ Although the Art. 107 TFEU prohibits aids to firms in the EU if they distort competition, it does not apply to transfers or equity injections to activities that belong to the public remit (see e.g. Leipzig/Halle airport case 2015/1469. Official Journal of the European Union, L232, 4 September 2015).

${ }^{21}$ In case of a default and takeover, the creditors may decide to sell the firm to a private investor. Assuming an efficient sale, they receive the same value. Our analysis remains unchanged.

${ }^{22}$ Under symmetric information the government ensures efficient output post liquidation. Under adverse selection, however, the government is forced to leave rents to creditors. For instance, defaulted national airline companies have full freedom to set their prices after the default and privatization stage.

${ }^{23}$ We make the assumption that experienced lenders are better informed than the government, and that there are no collective action or coordination problems among members of the creditor group. In Appendix $\mathrm{C}$ we briefly discuss the possible impact of bankruptcy or creditor auditing costs.
} 
the cost parameter directly after the firm defaults on its debt repayment. At that point of time, creditors have an informational advantage over the government. ${ }^{24}$ As a consequence, when the government relinquishes its control rights on the firm and the production decision is transferred to the creditors, the government's information deficit makes it unable to regulate a well-defined price on the defaulting firm. In this text, we avoid the discussion of renegotiation of inadequate regulated prices $^{25}$ (see Appendix $\mathrm{C}$ for a formal discussion of ex-post price cap). We assume that the defaulting firm gets no price and output restriction so that creditors are free to set laissez-faire prices after default and privatization. As a result, the output after privatization, $Q^{l}$, is given by the private monopoly output $Q^{m}(\beta) \equiv \arg \max _{Q} \Pi(\beta, Q)$.

The utilitarian government takes into account the consumer net surplus $N(Q)$, the social cost of public transfers, together with the utility of the state-owned firm and the creditors. The welfare function reads as:

$$
W_{2}\left(Q, T, \varphi, U_{2}, C_{2}\right)=[N(Q)-(1+\lambda) T](1-\varphi)+N\left(Q^{m}\right) \varphi+U_{2}+C_{2}
$$

where $-(1+\lambda) T$ represents socially costly transfers to the firm. In the spirit of Baron and Myerson (1982), the government has the ability to recoup the state-owned firm's profit by taxing the firm or cashing-in dividends in the second stage $(T<0)$. Subsidies or equity (re-)injection in the second stage $(T>0)$ can be used for the purpose of increasing output and consumer surplus. As in Laffont and Tirole (1993), the shadow cost of public funds, $\lambda$, reflects the balance between economic surplus and cost of government funding. The government concentrates on improving the economic surplus if $\lambda=0$ while it aims only at improving the Treasury balance if $\lambda \rightarrow \infty$.

The welfare can equivalently be written in several instructive forms. Plugging for the utility levels of manager and creditors, we get the welfare as function of outputs, transfers and debt level:

$$
W_{2}(Q, T, \varphi, D)=[N(Q)+\Pi(\beta, Q)](1-\varphi)+\left[N\left(Q^{m}\right)+\Pi\left(\beta, Q^{m}\right)\right] \varphi-D-\lambda T(1-\varphi) .
$$

The three first terms show the economic surpluses under operation and default and the debt paid to capital market. The last term shows the transfer is evaluated at the shadow cost of public funds. The same transfer may encompass many items: a subsidy to entice the state-owned firm to produce closer to the social optimum, a tax to finance the Treasury, a subsidy to debt repayment, and rents to the state-owned firm's manager and creditors.

\footnotetext{
${ }^{24}$ This is in line with Gale and Hellwig's (1985) view of bankruptcy being an informational event that allows creditors to learn the true state of the firm. However, in contrast to those authors we assume no audit cost at the time of the change of ownership for the sake of simplicity.

${ }^{25}$ The same assumption is made in the literature. For instance, in Spiegel and Spulbert (1994) and Cambini and Spiegel (2015), the price cap is decided before cost realisation and can never be renegociated.
} 
Finally, substituting the transfer $T$ by the manager's utility and the creditors' utility $C_{2}$ by its value, we get

$$
\begin{aligned}
W_{2}\left(Q, \varphi, U_{2}, R, D\right)=\{ & N(Q)+\Pi(\beta, Q)-\lambda[R-\Pi(\beta, Q)]-D\}(1-\varphi) \\
& +\left[N\left(Q^{m}\right)+\Pi\left(\beta, Q^{m}\right)-D\right] \varphi \\
& -\lambda U_{2}
\end{aligned}
$$

The first line shows the economic surplus, cost of debt and social cost of covering the firm loss $(R-\Pi)$ in an operating state-owned firm. The second line economic surplus net of debt under

privatization. Finally there is the social cost of manager's rents. Ceteris paribus, the ex-post welfare falls with a higher debt repayment $R$. It also decreases with debt if $\varphi>\lambda(1-\varphi)$. In this case, if the manager's rent $U_{2}$ was nil, there would be no point to raise debt.

We can now express the government's agency problem.

\subsection{Government's program}

In the first stage, the government maximizes the expected welfare $\mathcal{W}=W_{1}+\mathrm{E}\left[W_{2}\right]$, where $\mathrm{E}[f]=\int_{\underline{\beta}}^{\bar{\beta}} f(\beta) \mathrm{d} G(\beta)$ denotes the expectation operator on $f$. Creditors require a positive ex-ante pay-off $C_{1}+\mathrm{E}\left[C_{2}\right]$ to participate in the state-owned firm financing. This implies $\mathrm{E}\left[C_{2}\right] \geq 0$ since $C_{1}=0$. Whereas the manager is in charge of contracting the debt with creditors, she is given no freedom because the government can choose the equity amount $E$ that covers the investment cost net of debt, $E=K-D$, and that implies an amount of debt $D$ that creditors accept for the future repayment $R$. The manager thus gets no rent: $U_{1}=0$. Hence, it is the government that actually chooses the debt, equity and repayment levels $\{D, E, R\}$ that entice all parties to participate in the state-owned firm's financing.

Under asymmetric information, the government does not observe the realized cost parameter of the state-owned firm in the second stage. The state-owned firm manager may not report her cost parameter truthfully as she has an incentive to mimic a less efficient firm. The government must therefore design incentive compatible contracts such that she truthfully reveals her cost information. Being uninformed about the firms' cost $\beta$, the government proposes a menu of contracts $\{Q(\cdot), T(\cdot), \varphi(\cdot)\}$ that specifies the output, transfer and default option that maximizes its ex-post welfare $\mathrm{E}\left[W_{2}\right]$. Incentive compatibility requires that the manager reveals a cost report $\widehat{\beta}$ that maximizes her utility $U_{2}$ under the offered menu. While these contracts mitigate possible cost over-reporting or cost padding, they create information rents and make the state-owned firm 
less attractive for the government (Laffont, 2005, Auriol, 2006, Auriol and Blanc, 2009). Finally, to participate, the manager requires a non-negative utility level: $U_{2} \geq 0 \forall \beta$. Creditors either get the repayment $R$ or the right to the firm's cash-flow $\Pi\left(\beta, Q^{l}\right)$.

Formally, the government's program writes as follows:

$$
\max _{\{D, E, R\}} \mathcal{W}=W_{1}+\mathrm{E}\left[W_{2}^{*}\right] \text { s.t. } E+D=K \text { and } \mathrm{E}\left[C_{2}\right] \geq 0
$$

where

$$
\begin{gathered}
\mathrm{E}\left[W_{2}^{*}\right]=\max _{\{Q(\cdot), T,(\cdot), \varphi(\cdot)\}} \mathrm{E}\left[W_{2}\left(Q, T, \varphi, U_{2}, C_{2}\right)\right] \\
\text { s.t. } \quad \widehat{\beta} \in \max _{\beta^{\prime}} U_{2}\left[\beta, Q\left(\beta^{\prime}\right), T\left(\beta^{\prime}\right), \varphi\left(\beta^{\prime}\right)\right] \\
U_{2}[\beta, Q(\widehat{\beta}), T(\widehat{\beta}), \varphi(\widehat{\beta})] \geq 0
\end{gathered}
$$

Because no party have incentives to deviate in each stage, this setting yields a sub-game perfect equilibrium.

We make several remarks about the interpretation of the model. First, in this sub-game perfect equilibrium, the government asks the state-owned firm to set the output and induces the ownership structure that maximize the second stage welfare. It therefore has no incentives to change its output, price or default decision. In other words, the second stage output and ownership structure are immune to renegotiation. This set-up should be distinguished from the one in Cambini and Spiegel (2015) where prices and output are not ex-post optimal and the presence of distress costs induce price hikes. Also, it is worth being more precise on the commitment issue. The point here is not that the government must commit not to bail out the state-owned firm ex-post. It does implement its best option given information asymmetries. As discussed in Section 3, the point is however that the government must not have binding commitment to bail out the firm ex-post in debt contract guarantee clauses. Observe that, if guarantee clauses were imposed in all state-owned companies, we would never observe state-owned firms with bankruptcy problems, which would not match facts.

Second, while our model studies a separate set of decisions in each stage, it is obvious that the debt level and the incentive contracts can be both decided ex-ante. The output, transfer and default levels need simply be contingent on the cost report $\widehat{\beta}$. Here, again, the government may look like committed by its incentive contracts, but this contract always yields its second stage optimal option. Third, the manager maximizes her rent $U_{2}$ given the menu of contracts offered to her. As standard in the contract theory literature, the menu of contacts is indexed on her cost report $\widehat{\beta}$. In practice, such a menu is rather expressed as a "performance contract" that specifies 
transfer and default decisions $\{T, \varphi\}$ as functions of the achieved output or the allowed ex-post price. Such performance contracts were presented in Section 2 in the case of SNCF and SNCBNMVB. ${ }^{2627}$ In reality, cost pass-through provisions offer the flexibility to adjust on cost variations and are implemented with menus of price caps (Stones 2007).

Finally, the second stage of the above model focuses on a single time decision only for the sake of exposition. Indeed, as per Baron and Besanko (1984), our analysis of the second stage may be extended to the case where the second stage is repeated in several time periods. Those authors show that the optimal dynamic contract is simply the repetition of the static contract if the hidden cost parameter $\beta$ is repeatedly and independently drawn from the same distribution $G$. In such an extension, default may occur at any time period according to the realization of $\beta$ in the time period.

This subgame perfect equilibrium is solved backwards.

\section{Output and default decisions}

In the second stage the government maximizes the expected welfare subject to the firm manager's participation constraint and incentive compatibility constraint. By the Revelation Principle, it can implement a direct mechanism $\{Q(\cdot), T(\cdot), \varphi(\cdot)\}$ where the state-owned firm truthfully reports its cost information: $\widehat{\beta}=\beta$. As usual in contract theory (see Laffont and Martimort 2002), we can substitute the control variable $T$ for $U_{2}$. Using (2), the government's program becomes:

$$
\max _{Q(\cdot), U_{2}(\cdot), \varphi(\cdot)} \mathrm{E} W_{2}=\int_{\underline{\beta}}^{\bar{\beta}} W_{2}\left(Q, \varphi, U_{2}, R, D\right) \mathrm{d} G(\beta)
$$

subject to the incentive compatibility and participation constraints

$$
\begin{aligned}
\frac{\mathrm{d} U_{2}}{\mathrm{~d} \beta} & =(1-\varphi) \Pi_{\beta}(\beta, Q) \\
U_{2} & \geq 0
\end{aligned}
$$

The incentive compatibility constraint (4) is standard in the literature. ${ }^{28}$ It imposes that the manager of the state-owned firm incurs a sufficient fall in her utility when she reports a cost higher

\footnotetext{
${ }^{26}$ The performance contracts are given by $\left\{T\left[Q^{-1}(q)\right], \varphi\left[Q^{-1}(q)\right]\right\}$ where $q$ is the observed output or by $\left.\left\{T\left[Q^{-1}\left(P^{-1}(p)\right)\right], \varphi\left[Q^{-1}\left(P^{-1}(p)\right)\right)\right]\right\}$ where $p$ is the allowed price. Such formulation requires that $Q$ is strictly monotone and that $T$ and $\varphi$ are monotone functions of $\beta$. It will be the case under the assumptions of this paper.

${ }^{27}$ In our case, the government has full bargaining power in this ex-post negotiation. Cambini and Spiegel (2011) consider balanced bargaining powers of regulator and firm in the context of symmetric information.

${ }^{28}$ See Laffont and Tirole (1993) and Laffont and Martimort (2002). The firm's optimal cost report is $\widehat{\beta}(\beta) \in$ $\max _{\widehat{\beta}} U_{2}[\beta, Q(\widehat{\beta}), T(\widehat{\beta})]=\max _{\widehat{\beta}} \Pi(\beta, Q(\widehat{\beta}))+T(\widehat{\beta})-R$. Under truth revelation, $\beta=\widehat{\beta}(\beta)$, the utility is equal to $U_{2}[\beta, Q(\beta), T(\beta)]$, which yields, by the envelop theorem, yields $\mathrm{d} U_{2} / \mathrm{d} \beta=\Pi_{\beta}(\beta, Q(\beta))$.
} 
than her true cost. This condition is necessary and sufficient if $Q$ is monotone decreasing function of the cost parameter $\beta$. This will be true under the usual condition that the hazard rate $G / g$ is strictly increasing, which we assume from now on. Since $G(\underline{\beta})=0$, the hazard rate is nil at $\underline{\beta}$. When the cost uncertainty is infinitely small, the support of the distribution tends to a single point, $\underline{\beta} \rightarrow \bar{\beta}$, and the hazard rate to zero. To guarantee concavity of the above program, we further assume that $\Pi_{\beta}$ is not too convex in $Q$.

To simplify the exposition, we concentrate on the situation where there exists a unique cost threshold $\beta^{*}$ such that the state-owned firm is defaulted for cost reports higher than $\beta^{*}$. The condition for such a situation is made explicit below. In this case, $\varphi=0$ if $\beta \in\left[\underline{\beta}, \beta^{*}\right]$ and $\varphi=1$ for $\beta \in\left(\beta^{*}, \bar{\beta}\right]$. By $(4)$, it comes that the manager's utility falls from $U_{2}(\underline{\beta})$ to $U_{2}\left(\beta^{*}\right)$. Since the rents to state-owned manager imposes a social cost $\lambda U_{2}$, the government finds it optimal to set $U_{2}\left(\beta^{*}\right)=0$. Also, integrating by part the incentive condition (4), the manager's expected rent can be written $\mathrm{as}^{29}$

$$
\int_{\underline{\beta}}^{\bar{\beta}} U_{2} \mathrm{~d} G(\beta)=\int_{\underline{\beta}}^{\beta^{*}}\left(-\Pi_{\beta}\right) \frac{G}{g} \mathrm{~d} G(\beta)
$$

This identity expresses the government's main trade-off between state-owned firm's operation and default: if the government defaults for a wider range of high cost reports, it reduces the range and the rents of the low cost firms that benefit from information rents. As a result, it raises welfare.

Using the above, the above program can then be written as

$$
\mathrm{E}\left[W_{2}\right]=\int_{\underline{\beta}}^{\beta^{*}} W_{2}^{0}(\beta, R, D) \mathrm{d} G(\beta)+\int_{\beta^{*}}^{\bar{\beta}} W_{2}^{1}(\beta, D) \mathrm{d} G(\beta)
$$

where

$$
W_{2}^{0}(\beta, R, D)=\max _{Q}\left\{N(Q)+\Pi(\beta, Q)-D-\lambda[R-\Pi(\beta, Q)]+\lambda \frac{G}{g} \Pi_{\beta}(\beta, Q)\right\}
$$

and

$$
W_{2}^{1}(\beta, D) \equiv N\left(Q^{m}\right)+\Pi\left(\beta, Q^{m}\right)-D
$$

The ex-post welfare has the same structure as (2). The term $W_{2}^{0}$ includes the economic surplus, the cost of the debt, the social cost of covering the firm loss $(R-\Pi)$ in the operating state-owned firm. It includes an additional term related to information rents, $\lambda(G / g) \Pi_{\beta}$. The term $W_{2}^{1}$ includes the economic surplus and debt under default.

\footnotetext{
${ }^{29}$ Indeed, one computes $\int_{\underline{\beta}}^{\bar{\beta}} U_{2} \mathrm{~d} G(\beta)=\int_{\underline{\beta}}^{\bar{\beta}} U_{2} g \mathrm{~d} \beta=\left[U_{2} G\right]_{\underline{\beta}}^{\bar{\beta}}-\int_{\underline{\beta}}^{\bar{\beta}} \frac{\mathrm{d} U_{2}}{\mathrm{~d} \beta} G \mathrm{~d} \beta=-\int_{\underline{\beta}}^{\bar{\beta}}(1-\varphi) \Pi_{\beta} G \mathrm{~d} \beta=$ $-\int_{\underline{\beta}}^{\bar{\beta}}(1-\varphi) \Pi_{\beta}(G / g) \mathrm{d} G(\beta)$ since $G(\underline{\beta})=0$ and $U_{2}(\bar{\beta})=U_{2}\left(\beta^{*}\right)=0$.
} 


\subsection{Output decision}

The optimal output $Q^{*}$ of the state-owned firm is given by the FOC w.r.t. $Q$ of the objective in (7):

$$
\left(N_{Q}+\Pi_{Q}\right)+\lambda \Pi_{Q}+\lambda \frac{G}{g} \Pi_{\beta Q}=0 .
$$

Under our assumptions, the LHS of condition (8) is decreasing functions of $Q$ so that the condition yields a maximum. Four comments are in order.

First, in the absence of shadow cost of public funds $(\lambda=0)$, the government cares only about the economic surplus. The transfers between the Treasury, firm and manager imply income redistribution but does not affect its utilitarian objective. Then, the government asks the firm to implement the output that maximizes the economic surplus: $Q^{e}=\arg \max _{Q}(N+\Pi)$. Second, in the presence of a shadow cost of public funding $(\lambda>0)$ and in the absence of cost uncertainty $(G / g=0)$, the government balances the marginal increase in economic surplus and the social cost of subsidizing production $\left(\Pi_{Q}\right)$. In the limit where $\lambda \rightarrow \infty$, the government cares only about the dividend it can tap from the state-owned firm and asks to implement the laissez-faire monopoly level $Q^{m}(\beta)$, which solves $\Pi_{Q}=0$. Third, in the presence of a shadow cost of public funding $(\lambda>0)$ and cost uncertainty $(G / g>0)$, the government also considers the social cost of information extraction $\left((G / g) \Pi_{\beta Q}\right)$. Differentiating totally expression (8), it can be checked that the optimal output $Q^{*}$ decreases with the cost parameter $\beta$ as well as the shadow cost of public funds, $\lambda$. Higher cost parameters reduce the economic surplus and necessitates a smaller production level. Higher costs of public funds inflate the social cost of transfers to the firm and lead to a reduction in output for two reasons: one the one hand, it increases revenues and yields higher dividends to the Treasury or lower losses to recoup, on the other hand, it distorts output downward to lower the manager's incentive to mimic higher cost firms and therefore reduce information rents. Finally, observe that, instead of setting the output level, the government may set the market ex-post price such that $p=P\left(Q^{*}\right)$. As a result, higher cost parameters and costs of public funds lead to higher prices. Financially distressed government are then expected to allow higher prices in state-owned firms because they put higher social value on transfers to the Treasury and are therefore less incline to accept high information rents.

\subsection{Default decision}

The optimal decision to default is given by the threshold $\beta^{*}$ that maximizes $\mathrm{E}\left[W_{2}\right]$. From (6), it is clear that the government defaults the state-owned firm if and only if the ex-post welfare 
advantage of state-owned firm,

$$
\Delta W_{2}(\beta, R) \equiv W_{2}^{0}(\beta, R, D)-W_{2}^{1}(\beta, D)
$$

is negative. This expression falls with the debt repayment $R$ but it is independent of debt $D$ because debt is always paid back to the capital market. To verify that the default threshold $\beta^{*}$ is unique as assumed above, $\Delta W_{2}(\beta, R)$ must cross the horizontal axis at most once and from above as $\beta$ rises. A sufficient condition is that $\Delta W_{2}(\beta, R)$ falls with $\beta .^{30}$ That is,

$$
\frac{\mathrm{d} \Delta W_{2}}{\mathrm{~d} \beta}=\left[(1+\lambda) \Pi_{\beta}\left(\beta, Q^{*}\right)+\lambda \frac{\mathrm{d}}{\mathrm{d} \beta}\left(\frac{G}{g} \Pi_{\beta}\right)\right]-\left[\Pi_{\beta}\left(\beta, Q^{m}\right)+N_{Q}\left(Q^{m}\right) \frac{\mathrm{d} Q^{m}}{\mathrm{~d} \beta}\right]<0 .
$$

This condition reflects the balance in the welfare losses in the state-owned and privatized firms. It includes the effect of information extraction in the state-owned firm and the allocative inefficiency in the defaulted firm. To our knowledge, the sign of expression (10) is ambiguous for general profit functions and parameter distributions. It is however negative for linear demand and linear cost functions and uniform cost parameter distributions (see Appendix B). By continuity, the condition is fulfilled for neither too convex nor too concave demand functions. There exist many other classes of profit functions and parameter distributions that also satisfy this condition. To highlight the general properties of the model, we maintain the above general formulation of economic surpluses and rent rather than specialize to a specific class of surplus and profit functions that satisfy the above condition.

Under condition (10), there exists a unique optimal default threshold $\beta^{*}$ that solves $\Delta W_{2}\left(\beta^{*}, R\right)=$ 0 . Moreover, the default threshold $\beta^{*}$ decreases with repayment levels $R$ as $\mathrm{d} \beta^{*} / \mathrm{d} R=-\left(\partial \Delta W_{2} / \partial R\right)$ / $\left(\partial \Delta W_{2} / \partial \beta\right)<0$. This yields the following proposition.

Proposition 1 Under condition (10), there exists a unique optimal default threshold $\beta^{*}(R)$ such that the government defaults if and only if $\beta \geq \beta^{*}(R)$. The threshold $\beta^{*}$ is a decreasing function in $R$. This property holds for any combination of linear or iso-elastic demands, linear costs and uniform or Pareto distributions.

\section{Proof. See Appendix B.}

Under the structure of this optimal default threshold, there exist two repayment levels $\underline{R}$ and $\bar{R}$ such that firms are never defaulted when $R<\underline{R}$, only the firms with cost in the range $\left(\beta^{*}, \bar{\beta}\right]$ are defaulted when $R \in[\underline{R}, \bar{R}]$, and firms finally are always defaulted when $R>\bar{R}$. The latter

\footnotetext{
${ }^{30}$ This condition is sufficient. For many specifications, the same default structure is optimal even when this condition is not satisfied.
} 
situation is actually equivalent to privatize the firm for any cost realization. The government therefore has the option unconditionally to privatize the state-owned firm by setting $R>\bar{R}$ in the first stage.

We are now equipped to discuss the debt and equity transfer decision that the government makes in the first stage.

\section{Debt and equity decisions}

In the first stage no party has information about the cost parameter. The government maximizes its expected welfare subject to the firm manager's and creditors' participation constraints and subject to the output, transfer and default decisions made in the second stage.

\section{$5.1 \quad$ Expected welfare}

The expected welfare is given by $\mathcal{W} \equiv W_{1}+\mathrm{E}\left[W_{2}\right]$, or equivalently,

$$
\mathcal{W}=-(1+\lambda) E+\int_{\underline{\beta}}^{\beta^{*}(R)} W_{2}^{0}(\beta, R, D) \mathrm{d} G(\beta)+\int_{\beta^{*}(R)}^{\bar{\beta}} W_{2}^{1}(\beta, D) \mathrm{d} G(\beta)
$$

Using the amount of equity $E=K-D$ and changing the integration boundaries, this can be written as

$$
\mathcal{W}=-(1+\lambda)(K-D)+\int_{\underline{\beta}}^{\bar{\beta}} W_{2}^{0}(\beta, R, D) \mathrm{d} G(\beta)-\int_{\beta^{*}(R)}^{\bar{\beta}} \Delta W_{2}(\beta, R) \mathrm{d} G(\beta)
$$

where $\Delta W_{2}$ is presented in (9).

The expected welfare includes three elements: the social value of first stage equity injection, the expected value of ex-post welfare under state-ownership and the expected loss or benefit of letting the state-owned firm default.

Because rents to creditors have a social cost, the government finds it optimal to inject equity such that creditors are indifferent to the debt contract: $\mathrm{E}\left[C_{2}\right]=0$. This implies that the debt level is equal to the expected value of repayment and profit after defaulting:

$$
D=R G\left[\beta^{*}(R)\right]+\int_{\beta^{*}}^{\bar{\beta}} \Pi\left(\beta, Q^{m}\right) \mathrm{d} G(\beta)
$$

In Section 5.4, we will show that repayments $R$ are always higher than the operating profits $\Pi\left(\beta, Q^{m}\right)$ of defaulted firms, $\beta \in\left(\beta^{*}, \bar{\beta}\right]$. The second term in the RHS of $(12)$ is therefore smaller than $R\left[1-G\left(\beta^{*}\right)\right]$. This implies that the debt $D$ is always lower than the repayment $R$ made by the state-owned firm. 
Using expression (12) and the fact that $W_{2}^{0}(\beta, R, D)=W_{2}^{0}(\beta, 0,0)-\lambda R-D$, we can write the above expression in the following form:

$$
\mathcal{W}=-(1+\lambda) K+\int_{\underline{\beta}}^{\underline{\beta}} W_{2}^{0}(\beta, 0,0) \mathrm{d} G(\beta)-\int_{\beta^{*}(R)}^{\bar{\beta}}\left\{\Delta W_{2}(\beta, R)+\lambda\left[\Pi\left(\beta, Q^{m}\right)-R\right]\right\} \mathrm{d} G(\beta)
$$

Hence, the expected welfare is broken down in three parts: the social cost of funding the project, the expected welfare of the undefaulted state-owned firm and the expected loss or gain of defaulting. The two first parts are independent of the debt and repayment levels while the last one may $a$ priori depend on the repayment level. The last term not only includes the loss of the second stage ex-post welfare $\Delta W_{2}$ - as discussed above - but also the social benefit of contracting a debt in the first stage $\lambda\left[\Pi\left(\beta, Q^{m}\right)-R\right]$. Using $\Delta W_{2}(\beta, R)=\Delta W_{2}(\beta, 0)-\lambda R$, the integrand in the above third term simplifies to

$$
\Delta V(\beta) \equiv \Delta W_{2}(\beta, 0)+\lambda \Pi\left(\beta, Q^{m}\right)
$$

which is actually independent of the repayment level $R$. Importantly, it is also a decreasing function of $\beta$ since

$$
\frac{\mathrm{d} \Delta V}{\mathrm{~d} \beta}=\frac{\mathrm{d} \Delta W_{2}}{\mathrm{~d} \beta}+\lambda \frac{\mathrm{d}}{\mathrm{d} \beta} \Pi\left(\beta, Q^{m}\right) \leq 0
$$

Indeed, the second term is equal to $\lambda \Pi_{\beta}$ and therefore negative while the first term is also negative under condition (10). Furthermore, we can make explicit the components of this expression as

$$
\Delta V(\beta)=\left[N\left(Q^{*}\right)+(1+\lambda) \Pi\left(\beta, Q^{*}\right)+\lambda \frac{G}{g} \Pi_{\beta}\left(\beta, Q^{*}\right)\right]-\left[N\left(Q^{m}\right)+(1+\lambda) \Pi\left(\beta, Q^{m}\right)\right]
$$

This measures the ex-post welfare difference between the state-owned firm and laissez-faire production for each cost parameter $\beta$. It is a counterfactual value because the second square bracketed term measures the ex-post welfare that the government would obtain if it were to ask to implement the laissez-faire output. Expression (14) is positive in the three following cases: for the lowest cost parameter $(\beta=\underline{\beta})$, in the absence of information asymmetry $(G / g=0)$, in the absence of cost of public funds $(\lambda=0)$. In any case, the term with $\lambda G / g$ vanishes and the bracketed terms in (14) encompass the objective $N+(1+\lambda) \Pi$ that is evaluated at its maximizing output $Q^{*}$ and at the laissez-faire output $Q^{m}$. The first term is therefore larger than the second. Hence, it can be stated that $\Delta V$ falls in $\beta$ from a positive value at $\beta=\underline{\beta}$ and has at most one intersection with the zero axis. By contrast, it becomes negative for very high cost of public fund $(\lambda \rightarrow \infty)$. This is because the second bracketed term in (14) is the maximum of the profit function $\Pi$ which is larger than the objective included the first term $\Pi+\frac{G}{g} \Pi_{\beta}$. Those important properties will be used below. 


\subsection{Optimal debt and equity}

From the above, the expected welfare is a function of the repayment level $R$. It has three regimes. First, for low repayment levels $R<\underline{R}$, the debt is always paid back so that $\beta^{*}(R)=\underline{\beta}$. The expected welfare is then given by the constant

$$
\mathcal{W}^{0}=-(1+\lambda) K+\int_{\underline{\beta}}^{\bar{\beta}}\left[N\left(Q^{*}\right)+(1+\lambda) \Pi\left(\beta, Q^{*}\right)+\lambda \frac{G}{g} \Pi_{\beta}\left(\beta, Q^{*}\right)\right] \mathrm{d} G(\beta)
$$

where we plugged the value of $W_{2}^{0}(\beta, 0,0)$. This balances the investment cost and the second stage welfare with state-owned firm production. Second, for high repayment levels $R>\bar{R}$, the firm is always defaulted and privatized so that $\beta^{*}(R)<\beta$. The expected welfare is equal to $\mathcal{W}^{0}-\int_{\underline{\beta}}^{\bar{\beta}} \Delta V(\beta) \mathrm{d} G(\beta)$, which is also constant. Finally, for intermediate repayment levels $R \in$ $[\underline{R}, \bar{R}]$, the expected welfare is given by

$$
\mathcal{W}(R)=\mathcal{W}^{0}-\int_{\beta^{*}(R)}^{\bar{\beta}} \Delta V(\beta) \mathrm{d} G(\beta)
$$

Because $\mathrm{d} \beta^{*} / \mathrm{d} R<0$, this implies that

$$
\frac{\mathrm{d} \mathcal{W}}{\mathrm{d} R}=\Delta V\left(\beta^{*}\right) g\left(\beta^{*}\right) \frac{\mathrm{d} \beta^{*}}{\mathrm{~d} R} \leq 0 \Longleftrightarrow \Delta V\left(\beta^{*}\right) \geq 0
$$

We know that $\Delta V(\beta)$ falls with higher cost parameters $\beta$ from a positive value at $\underline{\beta}=\beta^{*}(\bar{R})$ to (possibly) negative values. Yet, if $\Delta V(\bar{\beta})<0$, there exists a unique $\operatorname{root} \widetilde{\beta} \in(\beta, \bar{\beta})$ such that $\Delta V(\beta)=0$ and there exists an associated repayment $\widetilde{R} \in(\underline{R}, \bar{R})$ such that $\widetilde{\beta}=\beta^{*}(\widetilde{R})$. Then, if $R<\widetilde{R}, \Delta V\left(\beta^{*}(R)\right)$ is negative and expected welfare rises with higher $R$. Otherwise, it is positive and expected welfare falls. In other words, the expected welfare reaches a maximum at $\widetilde{R}$. The debt level $\widetilde{D}$ is then given by (12), evaluated at $R=\widetilde{R}$. By contrast, if $\Delta V(\bar{\beta})>0$, the expected welfare always falls with repayments in the interval $[\underline{R}, \bar{R}]$ so that zero repayment and zero debt levels are optimal.

Figure 2 displays numerical examples with linear demand and cost and with uniform cost distribution. It plots the debt level and ex-ante welfare for several values of shadow costs of public funds. Optimal expected welfare, repayment, debt levels are denoted by a small circle. The figure confirms the existence of optimal debt as stated in the above proposition. For $\lambda=0.3$, the ex-ante welfare is maximal at $R=D=0$ so that the government has no incentives to ask the firm to take debt (see small circle to the left of each panel). For higher $\lambda$, the maximal ex-ante welfare is obtained for positive values of $R$. For instance for $\lambda=0.6$, the repayment is equal to $\widetilde{R}=0.194$ and the debt can be computed as $\widetilde{D}=0.179$, which implies a return on investment of $8 \%$ for the creditors $(0.194 / 0.179-1)$. The debt is also positive and higher for $\lambda=1$ and $\lambda=2$. 

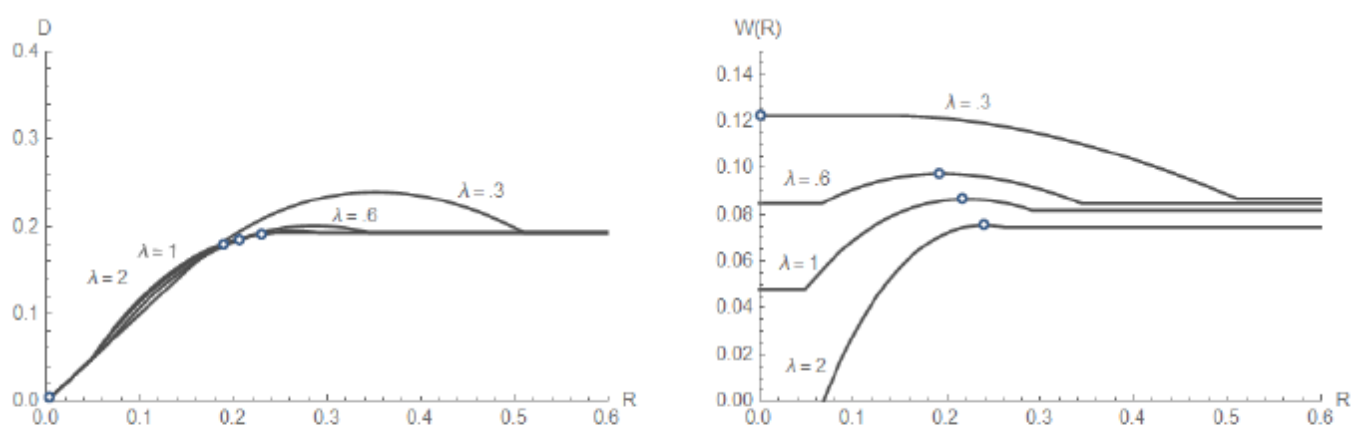

Figure 2: Numerical examples : Linear demand and cost and uniform distribution Note: $P(Q)=1-Q, \operatorname{Cos} t=\beta Q ; \Pi(\beta, Q)=(1-Q-\beta) Q ; K=.2 ; g(\beta)=4 ; \beta$ belongs to $[0,1 / 4]$.

We summarize this main finding in the following proposition.

Proposition 2 Under condition (10), debt increases expected welfare and the state-owned firm borrows if $\Delta V(\bar{\beta})<0$. If so, there exist two unique thresholds $\widetilde{\beta}$ and $\widetilde{R}$ solving $\Delta V(\widetilde{\beta})=0$ and $\beta^{*}(\widetilde{R})=\widetilde{\beta}$ so that the state-owned firm is asked to issue a positive debt $\widetilde{D}$. Otherwise, debt is not used.

Proposition 2 is our main result. It states that debt can be used as an instrument to reduce information rents in state-owned firms. The borrowing decision is the result of a trade-off between economic surplus, shadow cost of public funds and information rents. To make this clear we can look at the case without information asymmetry. In the absence of information asymmetry, we have $G / g=0$ and therefore $\Delta V(\beta) \geq 0 \forall \beta \in[\underline{\beta}, \bar{\beta}]$. So, expected welfare falls with $R \in[\underline{R}, \bar{R}]$ and is constant for other repayment levels. It therefore is always optimal to set zero repayment and debt. This is a reminiscence of the fact that unconstrained and benevolent governments cannot do worse than the market outcomes as they can always replicate the market outcomes. The use of external borrowing is never socially optimal in the absence of asymmetric information. This is congruent with the 'irrelevance of the cost-of-funds argument' obtained for concession contracts under symmetric information by Engel et al.'s (2013). Yet, when governments have limited information, they are unable to do so and they balance information rents with the cost of public funds and allocative inefficiencies. This gives the following corollary:

Corollary 3 Debt contracts are never optimal in the absence of information asymmetry.

Note that when state-owned firms default, they reduce their production. Production indeed become lower because defaulted firms have higher costs and set uncontrolled prices. The government is also indifferent to defaulting a marginal state-owned firm with cost $\widehat{\beta}$. If it defaults the 
latter, it accepts a fall in production and therefore a rise in price. This results in a loss in consumer surplus, which is compensated by shutting subsidy payments to the state-owned firm.

Corollary 4 Production is lower in defaulted firms. The production of the firm with cost $\widehat{\beta}$ falls if it is defaulted.

Proof. See Appendix B.

\subsection{Cost of public funds}

The shadow cost of public funds has a key effect on the incentives to make state-owned firms borrow. A higher $\lambda$ raises the government's incentive to reduce transfers from the Treasury. To diminish transfers and their information rent content, the government makes the state-owned firm default at lower cost realizations. This strategy can be implemented by setting higher repayment and debt levels. To show this, we can look at the situation with or without cost of public funds.

First, in the absence of cost of public funds $(\lambda=0)$, the debt is not optimal because $\Delta V(\beta)$ has been shown to be positive $\forall \beta \in[\underline{\beta}, \bar{\beta}]$. The government cares only about the economic surplus and puts no social cost on the transfers between the parties. Information rents do not make it to distort output and prices and do not entice it to increase the debt leverage in order to increase the state-owned firm manager's incentive to report truthfully. As a result, debt contracts are not optimal in the absence of shadow cost of public funds and therefore for financially unconstrained governments. This phenomenon may explain why most of the federally-, state- or city-owned firms in the developed economies borrow directly from their own government and therefore use the public funding capabilities for their investments. (e.g. Amtrak, see Table 1.)

By contrast, the last conclusion is reversed when the government faces a very tough budget constraint (say $\lambda \rightarrow \infty$ ). In this case, the government is only interested in collecting the stateowned firm's dividends and avoiding to equity injection. As we have shown above, $\Delta V(\beta) \leq 0$ $\forall \beta \in[\underline{\beta}, \bar{\beta}]$ for $\lambda \rightarrow \infty$. Hence, the expected welfare rises with larger $R$ in the interval $[\underline{R}, \bar{R}]$ and the government chooses a repayment level such that $R>\bar{R}$. As the state-owned firm is never able to repay this amount in the second stage, the government actually commits in the first stage to privatize the project in the second stage. More precisely, the government makes the investment $K$ and directly sells (or auction) the project to an external party (here, the creditors) for the amount $D$ equal to the expected laissez-faire profit $\int_{\underline{\beta}}^{\bar{\beta}} \Pi\left(\beta, Q^{m}\right) \mathrm{d} G(\beta)$. By doing this, it avoids the information rents in the agency problem with the state-owned firm's manager. The government has an incentive to do so if the expected laissez-faire profit is larger than $K$. In this case the investment cost $K$ is fully covered by the private party. 
In Appendix B, we generalize those results by showing that $\mathrm{d} \widetilde{D} / \mathrm{d} \lambda>0, \mathrm{~d} \widetilde{R} / \mathrm{d} \lambda>0$ and $\mathrm{d} \widetilde{\beta} / \mathrm{d} \lambda<0$. The following corollary summarizes those results:

Proposition 5 There exist two cost thresholds of public funds ( $\underline{\lambda}$ and $\bar{\lambda}, \underline{\lambda}<\bar{\lambda}$ ) such that debt contracts are not used when governments have weak financial constraints $(\lambda<\underline{\lambda})$. For more financially constrained governments $(\underline{\lambda} \leq \lambda<\bar{\lambda})$, the debt, repayment and default probability are positive and rise with higher cost of public funds. Governments under high financial constraints $(\lambda \geq \bar{\lambda})$ choose to privatize and auction the project at the outset.

Proposition 5 helps understanding the existence of a positive relationship between prices and debt when costs of public funds change. Indeed, by (8) and (17), both prices and debt levels rises with stronger information asymmetry. Indeed, when the hazard ratio $G / g$ becomes higher, the government has incentives to ask smaller output and higher prices (see (8)) at the same time as it is willing to inject a smaller amount of first stage equity, leading to higher repayments and debts (see (17)). This implies that debt and price levels move in the same direction in regulated industries because of heterogeneity in cost of public funds. There is no causality between debt and prices. This is consistent with Bortolotti et al.'s (2011) empirical findings that suggest that leverage and prices are correlated in regulated industries but that reject any causality effects in the case state-owned companies (see their Tables VIII and XI, columns 7).

Corollary 6 State-owned firms' prices and debt leverages are positively correlated.

\subsection{Transfers}

A natural question arises about the transfer value at which the government stops subsidizing or reinjecting equity in the state-owned firm. We here show that transfers increase with reported cost parameters and that government lets the state-owned firm default when the transfer becomes higher than a specific positive amount.

The transfer to state-owned firm with cost parameter $\beta \in[\underline{\beta}, \widetilde{\beta}]$ is equal to

$$
T(\beta)=\widetilde{R}-\Pi\left(\beta, Q^{*}\right)+U_{2}
$$

That is, the government matches the gap between the debt repayment and operational profit plus the manager's information rent. This transfer increases with higher cost parameter $\beta$. Indeed, after differentiating and simplifying, we get

$$
T^{\prime}(\beta)=-\Pi_{Q} \frac{\mathrm{d} Q^{*}}{\mathrm{~d} \beta}>0
$$


which is positive because the optimal output $Q^{*}$ is a decreasing function of $\beta$ and the marginal profits $\Pi_{Q}$ are positive at $Q^{*}\left(Q^{m} \geq Q^{*}\right)$. Hence, it becomes more costly for the Treasury to support higher cost firms and the government stops reinjecting cash for cost parameters above $\widetilde{\beta}$.

As seen above, the cost and repayment thresholds $(\widetilde{\beta}, \widetilde{R})$ are determined by the second stage optimality condition $\beta=\beta^{*}(R)$, which is the solution of the identity $\Delta W_{2}(\beta, R)=0$, and the first stage optimality condition $\Delta V(\beta)=0$, which is a short-cut notation for the integrand of (13), namely, $\Delta W_{2}(\beta, R)+\lambda\left[\Pi\left(\beta, Q^{m}\right)-R\right]=0$. Therefore, at the optimal cost and repayment thresholds $(\widetilde{\beta}, \widetilde{R})$, it must be that

$$
\widetilde{R}=\Pi\left(\widetilde{\beta}, Q^{m}\right)
$$

In words, the cost parameter $\widetilde{\beta}$ that makes the government indifferent to default or not also makes the creditors indifferent to take over the firm or not. Because $\Pi\left(\beta, Q^{m}\right)$ falls with higher $\beta$, this is the highest profit level in defaulted firms and creditors always earn less than the repayment amount promised in the debt contract $(\beta>\widetilde{\beta})$. As mentioned above, this implies that the debt is always smaller than the associated repayment. Indeed, by (12), we get

$$
\begin{aligned}
\widetilde{D} & =\widetilde{R} G(\widetilde{\beta})+\int_{\widetilde{\beta}}^{\bar{\beta}} \Pi\left(\beta, Q^{m}\right) \mathrm{d} G(\beta) \\
& <\widetilde{R} G(\widetilde{\beta})+\widetilde{R}[1-G(\widetilde{\beta})] \\
& =\widetilde{R}
\end{aligned}
$$

The transfer to state-owned firm with this cost parameter $\widetilde{\beta}$ is equal to $T(\widetilde{\beta})=\widetilde{R}-\Pi\left(\widetilde{\beta}, Q^{*}\right)$ because its manager's utility is set to her participation constraint $\left(U_{2}(\widetilde{\beta})=0\right)$. Substituting for the above result, this specific transfer can be written as

$$
T(\widetilde{\beta})=\Pi\left(\widetilde{\beta}, Q^{m}\right)-\Pi\left(\widetilde{\beta}, Q^{*}\right)
$$

which is positive because $Q^{m}$ yields the maximal value of operational profits. Because $T$ increases in $\beta$, this is the highest amount of equity injection or subsidy that the government is willing to put in the state-owned firm to avoid a default. The important point is that $T(\widetilde{\beta})>0$. That is, the government relinquishes the state-owned firm only if the latter needs the government to meet its debt repayment obligation. It has no incentive to relinquish its ownership of a state-owned firm that meets its debt obligation.

Proposition 7 The optimal repayment is equal to the highest profit level in defaulted firms. The ex-post transfers from the government rise with higher cost reports. When cost reports imply too 
high transfers, the government does not help the state-owned firm covering its debt obligation and lets it default.

\section{Discussion}

To our knowledge the role of information and debt in state-owned enterprises has not been highlighted in the literature. We want to make several remarks.

First, our analysis carries over a continuous set of types. This contrasts with a body of contract theory applications that focus on two-type models for simplicity purposes. However, as it must now be clear, the discussion of optimal debt requires the assessment of a range of types with binding participation constraints $\left(U_{2}(\beta)=0\right)$. To be relevant, a discrete-type model would require three cost types: one that never participates, one that participates depending on debt levels and one that always participates. Such a three-type model is not simpler and more general than the present model. They would further impose the discussion of cost distributions with three modes, which is even less realistic. We believe that the condition (10) imposed in our continuous type model is no more restrictive than the simplifying assumption of discrete types. The model accepts analytical solutions for combinations of linear or iso-elastic demands, linear costs and uniform or Pareto distributions, which is the realm of contract theory models.

Second, note that the debt contract is a part of an ex-ante mechanism that includes an output contract. Debt is not only used for the purpose of financing the investment as it is usual in finance. Besides reducing socially costly subsidies, it is used to alter the public management 's participation constraint and diminish monitoring costs. Debt makes high cost firms fail and default so that there is no point for non-defaulting firms to report high cost as well. Debt therefore reduces the extent of their information rents. The mechanism presented here is not (necessarily) optimal as one might replace the debt contract by an option, warrant, etc. ${ }^{31}$ This is the case of TVA that offers convertible bonds (see Section 2). However, in our opinion, a debt contract more closely fits real distress situations of state-owned firms and highlights an uncovered feature of debt structure of state-owned companies.

Finally, the present model focuses on the case of (local) natural monopoly markets served by state-owned companies that sell their output to consumers. This fits the markets for water, railways, etc. Actually, the properties of the model depends only the existence of a consumer net surplus $N(Q)$, production surplus $\Pi(\beta, Q)$, economic surplus $N(Q)+\Pi(\beta, Q)$, and information

\footnotetext{
${ }^{31}$ For instance, one may add ex-post subsidies to the privatized firm as in Auriol and Picard (2009). One may also replace the debt by an option.
} 
rents $(G / g) \Pi_{\beta}(\beta, Q)$, and a performance contract $\{Q, T, \varphi\}$. Our results do not directly rely on the existence of a market price $P(Q)$ for goods or services. The model may therefore be generalized to other situations. For instance, the model can be interpreted as one of (public) good provision by a state-owned firm with a performance contract $\{Q, T, \varphi\}$ where $Q$ is the verifiable quality of the good provided and $\beta$ the production cost of quality unit. The same conclusion about debt leverage can be obtained provided that the economic and profit surplus functions share the concavity and single crossing properties assumed in the paper.

\section{Conclusion}

In this article, we examine the role of private debt contracts in inducing cost revelation and improving the welfare of state-owned firms. We find that, debt leverage may enhance welfare when the state-owned firm has private information. The government then balances the information cost that must be paid to have the state-owned firm truthfully report its costs and the loss in consumer surplus when the government loses control over production and prices after it defaults and privatizes the state-owned firm. We show that the debt contract allows the government to reduce subsidies and information rents by defaulting the firm. We show that the optimal debt level increases when the cost of public funds rises.

In this text, we also present a set of case studies illustrating state-owned firms' strong indebtedness, mostly in developed countries and transition economies. The literature review presented by Megginson and Netter (2001) also highlights higher debt leverages in state-owned firms before their privatization in non-transition economies. Our analysis confirms the existence of strong incentives for high debt leverage and privatization in the state-owned firms operating in developing countries. Such countries indeed have large costs of public funds due to weak tax systems and large informal sectors (Auriol and Warlters, 2012). Casual facts support that view as, for instance, many African cases of privatization turned out to be liquidations (Sarbib 1997). However, to our knowledge, there is no systematic empirical research on the role of state-owned firms' debt in developing countries. Whereas such a research agenda is welcome, it will be needed to disentangle the incentives to recourse to outside finance with the disincentive created by the bad credit institutions in developing countries.

Our model revisits Baron and Myerson's (1982) and Laffont and Tirole's (1993) views of regulated firms and asymmetric information in the context of debt contracts. For the sake of conciseness, the paper discards the nonetheless important issues of moral hazard, regulatory opportunism, complementary tasks, information asymmetries between creditors and private manager. But those 
have been extensively discussed in the recent literature. The model can nevertheless readily be extended to the issues of corporate taxation, private cost of capital, foreign creditors and auditing costs whereas the introduction of price cap after privatization is a more difficult task (see Appendix C). The paper leaves room for further discussion on information and coordination costs in the bankruptcy process (Gale and Hellwig, 1985) or in a subsequent privatization auction (Arozamena and Weinschelbaum, 2006 and 2009, Burguet and Perry, 2007). Finally, it might be important to generalize the debt contract. For example, it may include the possibility of the creditors (or external investors) exercising an option that gives them the right to pay a price and take control and management of the state-owned firm. There may be a role for the introduction of convertible bonds where the ownership structure changes in case of low profit realizations.

Recent empirical works have attached importance on the role of outside finance in state-owned firms and/or PPPs (e.g. Bortolotti et al., 2011). However, several theories concur to explain the relationship between leverage and other observables. de Bettignies and Ross (2009) emphasize the role of politicians' re-election incentives, Cambini and Spiegel (2015) the role of regulators' opportunism, Iossa and Martimort (2015) the importance of creditors' information and expertise and this paper the role of information rents in state-owned firms. In the future, empirical research shall help disentangling between those theories that explain the role of debt in state-owned firms.

\section{References}

Alexander, J., D’Aunno, T. and Succi, M.J. "Determinants of Rural Hospital Conversion: A model of Profound Organizational Change." Medical Care, Vol. 34.1 (1996), pp. 29-43.

Arozamena, L. and Weinschelbaum, F. "A Note on the Suboptimality of Right-of-First-Refusal Clauses." Economics Bulletin, Vol. 24 (2006), pp. 1-5.

Arozamena, L. and Weinschelbaum, F. "The Effect of Corruption on Bidding Behavior in FirstPrice Auctions." European Economic Review, Vol. 53, pp. 645-657.

Auriol, E. "Corruption in Procurement and Public Purchase." International Journal of Industrial Organization, Vol. 24 (2006), pp. 867-885.

Auriol, E. and Blanc, A. "Capture and Corruption in Public Utilities: The Cases of Water and Electricity in Sub-Saharan Africa." Utility Policy, Vol. 17 (2009), pp. 203-216.

Auriol, E. and Laffont, J-J. "Regulation by Duopoly." Journal of Economics 8 Management Strategy, Vol. 1.3 (1992), pp. 507-533. 
Auriol, E. and Picard, P.M. "Infrastructure and Public Utilities Privatization in Developing Countries." The World Bank Economic Review, Vol. 23 (2008), pp. 77-100.

Auriol, E. and Picard, P.M. "Government Outsourcing: Public Contracting with Private Monopoly." The Economic Journal, Vol. 119 (2009), pp. 1464-1493.

Auriol, E. and Warlters, M. "The Marginal Cost of Public Funds and Tax Reform in Africa." Journal of Development Economics, Vol. 97 (2012), pp. 58-72.

Baron, D. P., and Besanko, D. "Regulation and Information in a Continuing Relationship." Information Economics and Policy, Vol. 1 (1984), pp. 267-302.

Baron, D.P. and Myerson, R.B. "Regulating a Monopolist with Unknown Costs." Econometrica, Vol. 50 (1982), pp. 911-930.

Bernet, P.M. and Getzen, T.E. "Can a Violation of Investor Trust Lead to Financial Contagion in the Market for Tax-exempt Hospital Bonds?" International Journal of Health Care Finance and Economics, Vol 8.1 (2008), pp. 27-51.

Borisova, G., Fotak, V., Holland, K. and Megginson, W.L. "Government Ownership and the Cost of Debt: Evidence from Government Investments in Publicly Traded Firms." Working Paper, Price College of Business, The University of Oklahoma, 2012.

Bortolotti, B., Cambini, C., Rondi, L. and Spiegel, Y. "Capital Structure and Regulation: Do Ownership and Regulatory Independence Matter?" Journal of Economics $\mathscr{G}$ Management Strategy, Vol. 20.2 (2011), pp. 517-564.

Burguet, R. and Perry, M.K. "Bribery and Favoritism by Auctioneers in Sealed-Bid Auctions." The B. E. Journal of Theoretical Economics, Vol. 7 (2007), Article 23.

Calzolari, G. and Scarpa, C. "Footloose Monopolies: Regulating a "National Champion"." Journal of Economics 83 Management Strategy, Vol. 8.4 (2009), pp. 1179-1214.

Cambini, C. and Spiegel, Y. "Investment and Capital Structure of Partially Private Regulated Firms." Journal of Economics \& Management Strategy, (2015), Forthcoming.

Capuano, C. and De Feo, G. "Privatization in Oligopoly: The Impact of the Shadow Cost of Public Funds." Rivista Italiana degli Economisti, Vol. 2 (2010).

Chang, H.J. "State-owned Enterprise Reform." National Development Strategies Policy Notes, United Nations Department for Economic and Social Affairs (UNDESA), New York. 
Correia da Silva, L., Estache, A. and Jarvela, S. "Is Debt Replacing Equity in Regulated Privatised Infrastructure in LDCs?" Utilities Policy, Vol. 14.2 (2006), pp. 90-102.

Cremer, H., Marchand, M. and Thisse, J.F. "The Public Firm as an Instrument for Regulating an Oligopolistic Market.” Oxford Economic Papers, Vol. 41 (1989), pp. 283-301.

Dasgupta, S., and Nanda, V. "Bargaining and Brinkmanship: Capital Structure Choice by Regulated Firms." International Journal of Industrial Organization, Vol. 11.4 (1993), pp. 475-497.

de Bettignies, J.-E. and Ross, T. W. "Public-private partnerships and the privatization of financing: An incomplete contracts approach." International Journal of Industrial Organization, Vol. 27.3 (2009), pp. 358-368.

Dewatripont, M. and Tirole, J. "A Theory of Debt and Equity: Diversity of Securities and ManagerShareholder Congruence.” The Quarterly Journal of Economics, Vol. 109 (1994), pp. 1027-1054.

Dewatripont, M. and Legros, P. "Public-private partnerships: contract design and risk transfer," EIB Papers 5/2005, European Investment Bank, Economics Department (2005).

D'Souza, J., and Megginson, W. L. "The Financial and Operating Performance of Newly Privatized Firms in the 1990s." Journal of Finance, Vol. 54 (1999), pp. 1397-1438.

Engel, E., Fischer, R. and Galetovic, A. "The Economics of Infrastructure Finance: Public-Private Partnerships versus Public Provision." European Investment Bank Papers, Vol. 15.1 (2010), pp. 40-69.

Engel, E., Fischer, R. and Galetovic, A. "The Basic Public Finance Of Public-Private Partnerships." Journal of the European Economic Association, Vol. 11 (2013), pp. 83-111.

Estache, A., Guasch, J.L., Iimi, A. and Trujillo, L. "Multidimensionality and Renegotiation: Evidence from Transport Sector PPP Transactions in Latin America." Review of Industrial Organization, Vol. 35 (2009), pp. 41-71.

Estache, A., Tovar, B. and Trujillo, L. "How Efficient are African Electricity Companies? Evidence from Southern African Countries." Energy Policy, Vol. 36 (2008), pp. 1969-1979.

Estache A. and Saussier S. "Public-Private Partnerships and Efficiency: A Short Assessment," CESifo DICE Report, Vol. 12(3) (2014), pp. 08-13.

Faure-Grimaud, A. "Product Market Competition and Optimal Debt Contracts: The Limited Liability Effect Revisited." European Economic Review, Vol. 44 (2000), pp. 1823-1840. 
Gale, D. and Hellwig, M. "Incentive-Compatible Debt Contracts: The One-Period Problem." Review of Economic Studies, Vol. LII (1985), pp. 647-663.

Guasch, J.L., Laffont, J.J. and Straub, S. "Renegotiation of Concession Contracts: A Theoretical Approach." Review of Industrial Organization, Vol. 29 (2006), pp. 55-73.

Holmstrom, B. and Tirole, J. "Financial Intermediation, Loanable Funds, and the Real Sector." The Quarterly Journal of Economics, Vol. 112 (1997), pp. 663-691.

Iossa, E., Spagnolo, G. and Vellez, M. "Contract Design in Public Private Partnerships." Report prepared for the World Bank, 2007.

Jullien, Bruno. "Participation Constraints in Adverse Selection Models." Journal of Economic Theory, Vol. 93-1 (2000), pp 1-47.

Iossa, E. and Martimort, David. "Risk Allocation and the Costs and Benefits of Public-Private Partnerships." The RAND Journal of Economics, Vol. 43.3 (2012), pp. 442-474.

Klein, M. "Infrastructure Policy: Basic Design Options." World Bank Policy Research Working Paper, No. 6274 (2012).

Laffont, J.J. Regulation and Development. Cambridge, UK: Cambridge University Press, 2005.

Laffont, J.J. and Tirole, J. A Theory of Incentives in Procurement and Regulation. Cambridge, MA: MIT Press, 1993.

Langabeer, J. "Predicting Financial Distress in Teaching Hospitals." Journal of Health Care Finance, Vol. 33.2 (2006), pp. 84-92.

Leite, T. "Optimal Financial Structure: An Incomplete Contracting Model", Scandinavian Journal of Economics, Vol. 103 (2001), pp. 707-722.

Laffont, J.J. and Martimort, D. The Theory of Incentives - The Principal Agent Model. Princeton and Oxford: Princeton University Press, 2002.

Martimort, D. and Pouyet. "To build or not to build: Normative and positive theories of publicprivate partnerships." International Journal of Industrial Organization, Vol. 26 (2008), pp. 393411.

Menezes, F. and Ryan, M. "Default and Renegotiation in Public-Private Partnership Auctions." Journal of Public Economic Theory, Vol 17 (2015), pp. 49-77.

McCue, M.J. "Association of HMO Penetration and Other Credit Quality Factors with TaxExempt Bond Yields." Inquiry, Vol 34.3 (1997), pp. 217-227. 
Megginson, W.L., Nash, R. and van Randenborgh, M. "The Financial and Operating Performance of Newly Privatized Firms: An International Empirical Analysis." Journal of Finance, Vol. 49 (1994), pp. 403-452.

Megginson, W.L. and Netter, J. "From State to Market: A Survey of Empirical Studies on Privatization." Journal of Economic Literature, Vol. 39 (2001), pp. 321-389.

Moore, A., Straub, S. and Dethier, J. "Regulation, Renegotiation and Capital Structure: Theory and Evidence from Latin American Transport Concessions." Journal of Regulatory Economics, Vol. 45.2 (2014), pp. 209-232.

Menezes, F. and Ryan, M. "Default and Renegotiation in Public-Private Partnership Auctions." Journal of Public Economic Theory, Vol 17, (2015) pp. 49-77.

Myers, S.C. "Capital Structure." Journal of Economic Perspectives, Vol. 15 (2001), pp. 81-102.

National Audit Office (NAO), "The Economic Regulation of the Water Sector." Report by the Comptroller and Auditor General, October (2015).

Picard, P.M. and Rusli, R.D. "State-Owned Firms: Private Debt, Cost Revelation and Welfare." CREA Discussion Paper Series, Center for Research in Economic Analysis, University of Luxembourg, 12.10 (2012).

Povel, P. and Raith, M. "Financial Constraints and Product Market Competition: Ex-ante vs. Expost Incentives." International Journal of Industrial Organization, Vol. 22 (2004), pp. 917-949.

Ramamonjiarivelo, Z. "The Antecedents and consequences of Public Hospital Privatization." Dissertation at the University of Alabama in Birmingham, (2012).

Ramamonjiarivelo, Z., Weech-Maldonado, R., Hearld, L., Menachemi, N., Epane, J.P. and O'Connor, S. "Public Hospitals in Financial Distress: Is Privatization a Strategic choice?" Health Care Management Review, July (2014).

Sarbib, J-L. "Privatization in Africa: Present and Future Trends." African Development Bank Group, Annual Meeting Symposium on 'Private Sector Development In Africa. (1997).

Spiegel, Y. and Spulber, D.F. "The Capital Structure of a Regulated Firm." The RAND Journal of Economics, Vol. 25 (1994), pp. 424-440.

Tirole, J. The Theory of Corporate Finance. Princeton, NJ: Princeton University Press, 2005.

World Bank. "World Development Indicators," Washington D.C. World Bank (1998). 
World Bank. "Bankruptcy of State Enterprises in China: A Case and Agenda for Reforming the Insolvency System." East Asia and Pacific Region, Private Sector Development Unit, (2001).

Yescombe, E. Public-Private Partnerships: Principles of Policy and Finance. Oxford, UK: ButterworthHeinemann, 2011. 


\section{Appendix A: Case study references}

In this appendix we present the references to the sources used in our case studies. Those include annual reports, company statutes, compant websites and press articles.

\section{SNCF}

[1] Rapport annuel 2015. http://medias.sncf.com/sncfcom/pdf/finance/rapport_financier/SNCF _ RF2015_Groupe_complet.pdf

[2] http://fr.reuters.com/article/businessNews/idFRKBN0OC19S20150527

[3] http://www.sncf.com/fr/portrait-du-groupe/conseil-administration

[4] http://www.sncf.com/fr/portrait-du-groupe/epic

[5] "L’Europe n’impose pas de cadre strict à la réforme française". Les Echos. 19 June 2014. Online. Factiva. (October 2016)

[6] "L'État refuse de changer le statut de la SNCF". Le figaro. 1 June 2010. Online. Factiva. (October 2016)

[7] " "Le sujet est clos" sur le statut de la SNCF, assure M. Pépy". Agence France Presse. 2 June 2010. Online. Factiva. (October 2016)

[8] "Un an après la réforme ferroviaire, le plus dur reste à venir pour la « nouvelle SNCF »". Les Echos. 16 July 2015. Online. Factiva. (October 2016)

\section{Deutsche Bahn}

[1] http://www.deutschebahn.com/de/konzern/konzernprofil/aufsichtsrat.html

[2] Articles of association. http://www1.deutschebahn.com/ecm2-db-en/ir/cg/article_association.html [3] http://www1.deutschebahn.com/ecm2-db-en/ir/bonds_rating/financial_debt.html

[4] https://www.cash.ch/news/politik/milliardenspritze-fur-die-deutsche-bahn-mehr-zuschusse-fur -bus-und-bahn-493518

[5] Annual Report 2016. http://www1.deutschebahn.com/ecm2-db-en/ir/financial_reports/ [6] "Deutsche Bahn to be partially privatised by 2009". Agence France Presse. 8 November 2006. [7] "German Govt 09 New Debt Goal Raised To EUR18.5B". Dow Jones International News. 21 November 2008.

\section{SNCB}

[1] Rapport de gestion 2014.http://www.belgianrail.be/fr/corporate/sous-la-loupe/ /media/ 544FC94150064D6BAC7A3E617D68906D.ashx

[2] Loi du 30 août 2013 relative àa la réforme des chemins de fer belges. http://www.ejustice.just. fgov.be/cgi/article_body.pl?language $=$ fr\&caller $=$ summary\&pub_date $=13-09-13 \&$ numac $=$ 2013014495\#top 
[3] Comptes annuels de 2015. http://www.belgianrail.be/fr/corporate/sous-la-loupe/ /media /03454995A5F94BA6AE54ACDAB78BBFB7.ashx

[4]"RÉGIONALISATION DU RAIL : L'EXCEPTION BELGE; LE DOSSIER TABOU". Trends Tendances. 21 January 2016. Online. Factiva. (October 2016)

[5] "Perspective d'une privatisation de la SNCB". Agence Belga. 27 Novembre 2014. Online. Factiva. (October 2016)

\section{Amtrak}

[1] Amtrak National Facts, Amtrak, www.amtrak.com/servlet/ContentServer?c=Page\&pagename $=$ am\%2FLayout\&cid=1246041980246, accessed in October 2016.

[2] Amtrak. 2014 annual report of Amtrak. Retrieved from www.amtrak.com/servlet/ContentServer? $\mathrm{c}=$ Page\&pagename $=$ am\%2FLayout\&cid $=1241245669222$

[3] "BROOKS ASKS HOUSE TO END TAXPAYER SUBSIDIES FOR AMTRAK." Congressional Documents and Publications. 4 June 2015. Online. Factiva. (October 2016)

\section{EDF}

[1] https://www.edf.fr/groupe-edf/espaces-dedies/finance/informations-financieres/l-action-edf/ structure-du-capital

[2] Rapport financier annuel 2015. page 209, https://www.edf.fr/sites/default/files/contrib/groupeedf/espaces-dedies/espace-finance-fr/informations-financieres/informations-reglementees/documentde-reference/edf-ddr-2015-vf-doc-web.pdf

[3] http://www.lesechos.fr/25/04/2016/LesEchos/22178-050-ECH_l-etat-vole-au-secours-d-edf.htm [4] "Les avantages "exorbitants" du statut d'Epic". La Tribune. 23 June 2014. Online. Factiva. (October 2016)

[5] "EDF ouvre son capital dans un marché européen libéralisé". Agence France Presse. 24 October 2005. Online. Factiva. (October 2016)

[6] "LEAD 2 Rapprochement EDF-Veolia au moins industriel, dit Proglio". Reuters. 26 November 2009. Online. Factiva. (October 2016)

[7] "Une privatisation partielle pour EDF ?". Trends Tendances. 23 October 2014. Online. Factiva. (October 2016)

[8] http://fr.reuters.com/article/businessNews/idFRKBN0OC19S20150527

\section{TVA}

[1] TVA. 2015 annual report of TVA. Retrieved from www.snl.com/IRW/AsReported/4063363/Index 
[2] TVA - Board of Directors, TVA, www.tva.com/About-TVA/Our-Leadership/Board-of-Directors, accessed in October 2016.

[3] "Time to think about privatizing the TVA; Obama is right to consider such a change for the 80-year-old agency." The Washington Post. 26 April 2013. Online. Factiva. (October 2016)

[4] TVA - Investor Relations, TVA, https://www.tva.gov/About-TVA/Investor-Relations, accessed in October 2016. http://www.investinganswers.com.

\section{ENI spa}

[1] https://www.eni.com/en_IT/company/governance/shareholders.page

[2] www.eni.com

[3] https://www.eni.com/en_IT/investors/market-rating/credit-rating-and-debt.page

[4] http://fr.reuters.com/article/businessNews/idFRKCN0WK1M8

[5] http://fr.reuters.com/article/frEuroRpt/idFRL8N1BW52Z

[6] https://www.eni.com/en_IT/documentations.page

[7] "Italy's Renzi says Eni share sale depends on market conditions". Reuters. 29 December 2014. Online. Factiva. (October 2016)

[8] "Oil Price Fall Sees Eni Selloff Put On Hold; With Shares Down 25\%, Government Delays Privatization". WSJ. 19 December 2014. Online. Factiva. (October 2016)

\section{Hydro-Quebec}

[1] Hydro-Québec. 2015 annual report of Hydro-Québec. Retrieved from www.hydroquebec.com/ publications/en/corporate-documents/annual-report.html

[2] Relations avec les investisseurs, Hydro-Québec. www.hydroquebec.com/relations-investisseurs, accessed in October 2016.

[3] Yakabuski, Konrad. "Sell Hydro-Québec? Sounds good. It'll never happen." The Globe and Mail. 4 February 2009. Online. Factiva. (October 2016)

[4] Loi de 1983 concernant la société Hydo-Québec. http://legisquebec.gouv.qc.ca/fr/ShowDoc /cs/H-5

\section{TAP Portugal}

[1] TAP. 2014 annual report of TAP. Retrieved from www.tapportugal.com/Info/en/about-tap/tapgroup/annual-reports

[2] "SAirGroup withdraws from plan to buy TAP Air Portugal stake." Agence France Presse. 1 Februar 2001. Online. Factiva. (October 2016)

[3] "TAP-Portugal flies back into the red due to rising fuel costs." Agence France Presse. 3 April 2006. Online. Factiva. (October 2016) 
[4] "Aviation: le Portugal cède 61\% de la TAP à David Neeleman." Agence France Presse. 11 June 2015. Online. Factiva. (October 2016)

[5] Almeida, Henrique. "Portugal Reverses TAP Privatization Plan, Raising Stake to 50\%."

Bloomberg. 6 February 2016. Retrieved from www.bloomberg.com/news/articles/2016-02-06/ portugal-reverses-tap-privatization-plan-raising-stake-to-50

[6] Wise, Peter. "Portugal to unwind TAP Air privatization." Financial Times. 7 February 2016. Online. Retrieved from: www.ft.com/content/c408293c-cda5-11e5-831d $-09 \mathrm{f} 7778 \mathrm{e} 7377$

\section{Royal Mail plc}

[1] Royal Mail. 2015-2016 annual report and accounts. Retrieved from www.royalmailgroup.com/investorcentre/report-download-centre

[2] Moses, Anna and Lorna Booth. "Privatisation of Royal Mail." Briefing paper 066658. House of Commons Library. 15 January 2015. Retrieved from researchbriefings.files.parliament.uk/ documents/SN06668/SN06668.pdf

[3] Hooper, Richard. "Saving the Royal Mail's universal postal service in the digital age: An Update of the 2008 Independent Review of the Postal Services Sector." Independent report for the government of the UK. 10 September 2010. Retrieved from www.gov.uk/government/publications/savingthe-royal-mails-universal-postal-service-in-the-digital-age-an-update-of-the-2008-independent-review [4] Royal Mail Plc , Financial Times, markets.ft.com/data/equities/tearsheet/financials?s=RMG:LSE, accessed October 2016

[5] Privatisation, Royal Mail plc, www.royalmailgroup.com/about-us/privatisation, accessed in October 2016.

[6] "Royal Mail privatisation bill unveiled by Vince Cable." BBC News. 13 October 2010. Retrieved from: http://www.bbc.com/news/business-11526179"

[7] Royal Mail. 2010-2011 annual report and accounts. Retrieved from www.royalmailgroup.com/investor -centre/report-download-centre [8] Royal Mail. 2011-2012 annual report and accounts. Retrieved from www.royalmailgroup.com/investor-centre/report-download-centre 


\section{Appendix B: Proofs}

\section{Proof of Proposition 1}

We show that $\Delta W_{2}(\beta, R)$ is a decreasing function of $\beta$ for the classes of models with linear costs, Pareto and uniform distribution and linear or iso-elastic demand functions. Let us normalize $\underline{\beta}=0$ so that $\beta \in[0, \bar{\beta}]$, which does not change our results. We assume Pareto cumulative distribution function $G(\beta)=(\beta / \bar{\beta})^{\kappa}$ where $\kappa>0$ so that we conveniently have $G / g=\beta / \kappa$. The distribution is uniform if $\kappa=1$.

Consider first the linear inverse demand functions $P(Q)=a-b Q$ where $a$ and $b$ are positive scalars. Normalizing prices and output appropriately, we can restrict our study to the function $P(Q)=1-Q$ under the condition that $P(0) \geq \beta \Longleftrightarrow \beta \in[0,1]$. In this case, $S(Q)=Q-Q^{2} / 2$, $N(Q)=Q^{2} / 2$ and $\Pi(\beta, Q)=(1-\beta-Q) Q$. The default output is equal to $Q^{m}=(1-\beta) / 2$ and state-owned firm's output is computed as

$$
Q^{*}=(1-\beta)\left(\frac{1+\lambda}{1+2 \lambda}\right)\left(1-\frac{1}{\kappa} \frac{\lambda}{1+\lambda} \frac{\beta}{1-\beta}\right)
$$

which is a decreasing function of $\beta$ and which restricts $\bar{\beta}$ to be lower than $(1+\lambda) /(1+\lambda+\lambda / \kappa)$ to keep non negative output $Q^{*}$. Using the first order condition (8) applied to this linear demand, we can write $N\left(Q^{*}\right)+(1+\lambda) \Pi\left(\beta, Q^{*}\right)+\lambda(G / g) \Pi_{\beta}\left(\beta, Q^{*}\right)=\frac{1}{2}(1+2 \lambda)\left(Q^{*}\right)^{2}$ while $N\left(Q^{m}\right)+\Pi\left(\beta, Q^{m}\right)=$ $\frac{3}{2}\left(Q^{m}\right)^{2}$. Hence,

$$
\Delta W_{2}(\beta, R)=\frac{1}{2}(1-\beta)^{2}\left[\frac{(1+\lambda)^{2}}{1+2 \lambda}\left(1-\frac{1}{\kappa} \frac{\lambda}{1+\lambda} \frac{\beta}{1-\beta}\right)^{2}-\frac{3}{4}\right]-\lambda R
$$

where both terms fall in $\beta$. So, $\Delta W_{2}(\beta, R)$ is a decreasing function of $\beta$. As a consequence, for any repayment $R>0$, there will exist a unique threshold $\beta^{*}(R)$ such that $\Delta W_{2}(\beta, R)=0$. This threshold is decreasing in $R$.

Consider now the iso-elastic inverse demand functions $P(Q)=A Q^{-1 / \varepsilon}$, where we can also normalize the constant $A$ to one. The default output is equal to $Q^{m}=\left(e_{m} \beta\right)^{-\varepsilon}$ where $e_{m}=\varepsilon /(\varepsilon-1)$ and the state-owned firm's output is computed as $Q^{*}=(e \beta)^{-\varepsilon}$ where here $e \equiv \varepsilon(1+\lambda+\lambda / \kappa) /$ $[1+(1+\lambda)(\varepsilon-1)]$. So, $Q^{*}$ is a decreasing function of $\beta$. We compute $\Delta W_{2}(\beta, R)=\Delta W_{2}^{*} \beta^{1-\varepsilon}-\lambda R$ where

$$
\Delta W_{2}^{*} \equiv\left(e^{1-\varepsilon}-e_{m}^{1-\varepsilon}\right)[1+\lambda+1 /(\varepsilon-1)]-(1+\lambda)\left(e^{-\varepsilon}-e_{m}^{-\varepsilon}\right)-\lambda e^{-\varepsilon} / \kappa+\lambda e_{m}^{-\varepsilon} /(\varepsilon-1)
$$

One can show that $\Delta W_{2}^{*}$ is positive for low enough parameters $\varepsilon$ and $\lambda$ and negative otherwise. As a result, if $\Delta W_{2}^{*}>0$, there will exist a unique threshold $\beta^{*}(R)$ such that $\Delta W_{2}(\beta, R)=0$. This 
threshold is equal to $\beta^{*}(R)=\left(\lambda R / \Delta W_{2}^{*}\right)^{1 /(1-\varepsilon)}$, which is decreasing in $R$. Otherwise, if $\Delta W_{2}^{*} \leq 0$, $\Delta W_{2}(\beta, R)$ is always negative for $R \geq 0$ and the government chooses to privatize for all $\beta$. So, $\beta^{* *}(R)=0$. Intuitively, a high demand elasticity $\varepsilon$ or a high shadow cost of public funds $\lambda$ reduces government's concern about consumer surplus and its welfare cost of privatization, which entices it to privatize anyway.

\section{Proof of Corollary 4}

We first show that $Q^{*}(\widetilde{\beta}) \geq Q^{m}(\widetilde{\beta})$. Let us define the welfare objective $F(Q) \equiv N(Q)+(1+\lambda)$ $\Pi(\beta, Q)$. This is a function that increases on the interval $\left[0, Q^{*}\right]$ where $Q^{m} \leq Q^{*}$. Using (14), $\Delta V(\widetilde{\beta})=0$ is equivalent to $F\left[Q^{*}\right]-F\left[Q^{m}\right]=-\lambda \frac{G}{g} \Pi_{\beta}\left(\beta, Q^{*}\right)>0$ where is evaluated at $\beta=\widetilde{\beta}$. Therefore $F\left[Q^{*}(\widetilde{\beta})\right]>F\left[Q^{m}(\widetilde{\beta})\right] \Longleftrightarrow Q^{*}(\widetilde{\beta}) \geq Q^{m}(\widetilde{\beta})$, which is true.

Second, we show that production is lower in defaulted firms. That is, $Q^{*}\left(\beta^{\prime}\right) \geq Q^{m}\left(\beta^{\prime \prime}\right)$ for any $\beta^{\prime} \leq \widetilde{\beta} \leq \beta^{\prime \prime}$. This is true because $Q^{*}\left(\beta^{\prime}\right)>Q^{*}(\widetilde{\beta})$ for $\beta^{\prime}<\widetilde{\beta}, Q^{*}(\widetilde{\beta}) \geq Q^{m}(\widetilde{\beta})$ and $Q^{m}(\widetilde{\beta})>Q^{m}\left(\beta^{\prime \prime}\right)$ for $\widetilde{\beta}<\beta^{\prime \prime}$.

\section{Proof of Proposition 5}

First, we get $\mathrm{d} \widetilde{\beta} / \mathrm{d} \lambda=-(\mathrm{d} \Delta V / \mathrm{d} \lambda) /(\mathrm{d} \Delta V / \mathrm{d} \beta)<0$ because $\mathrm{d} \Delta V / \mathrm{d} \beta<0$ and $\mathrm{d} \Delta V / \mathrm{d} \lambda=$ $\left[\Pi\left(\beta, Q^{*}\right)+(G / g) \Pi_{\beta}\left(\beta, Q^{*}\right)\right]-\Pi\left(\beta, Q^{m}\right)<0$. Indeed, we have $\Pi\left(\beta, Q^{m}\right) \geq \Pi(\beta, Q)>\Pi(\beta, Q)+$ $(G / g) \Pi_{\beta}(\beta, Q)$ for any $Q$ because $\Pi_{\beta}<0$. Second, by (17), we get $\mathrm{d} \widetilde{R} / \mathrm{d} \lambda=\Pi_{\beta}\left(\widetilde{\beta}, Q^{m}\right) \mathrm{d} \widetilde{\beta} / \mathrm{d} \lambda>0$. Finally, $\mathrm{d} \widetilde{D} / \mathrm{d} \lambda>0$ because $\widetilde{D}$ lies on the upward sloping section of (12). 


\section{Appendix C: Extensions}

In this Appendix, we shortly expand the model to explain the role of the investment cost, corporate taxes, price cap, private cost of capital and time discounting and finally the impact of foreign creditors.

\section{Investment costs}

In our analysis, the optimal debt level $\widetilde{D}(\widetilde{R})$ depends on the state-owned firm's ability to meet its repayment commitment $\widetilde{R}$. This ability is influenced by the firm's capacity to generate profits and therefore on its product demand and cost parameter distribution. It is however not related to the investment cost $K$. So, what can be the impact of this cost on our previous discussion?

If the optimal debt level is lower than the investment cost $(\widetilde{D}(\widetilde{R})<K)$, the state-owned firm is limited in its ability to raise funds and the government is obliged to contribute to the equity for an amount of $E=K-\widetilde{D}(\widetilde{R})>0$. In this case our analysis remains the same. By contrast, if the optimal debt level is higher than the investment cost $(\widetilde{D}(\widetilde{R})>K)$, the state-owned firm is able to raise more than its investment cost. This leads to two possibilities. On the one hand, the government may inject negative equity into the state-owned firm, meaning that it collects $\widetilde{D}(\widetilde{R})-K$ in the first stage and saves on public funding for the same amount. In that case our analysis is also unchanged. On the other hand, the investment cost $K$ may consist of a cap on the borrowing possibilities. This can be motivated by moral hazard issues that are not modeled here: the infrastructure is the only physical asset that the creditors can seize and that is pledgeable. In such a situation, the optimal debt is constrained to $\widetilde{D}(R)=K$. This gives a maximum repayment $R$ equal to $\widetilde{D}^{-1}(K)$. The introduction of this moral hazard constraint shifts the debt level from $\widetilde{D}(\widetilde{R})$ to $K$.

\section{Corporate taxes}

In most countries, privatized firms are subject to corporate taxes. The introduction of such tax can readily be included in our analysis with little analytical effort. Indeed, suppose that a corporate tax rate $\tau$ is imposed on the defaulted and privatized firm. Ex-post, the welfare is augmented by the amount $\tau \Pi\left(\beta, Q^{m}\right)$ in all default situations which are evaluated at the shadow cost $\lambda$. The tax does not change the welfare in state-owned firms. This clearly gives an additional advantage to the default option and reduces the cost parameters at which the government chooses to liquidate the firm. More formally, the presence of the corporate tax decreases the welfare advantage $\Delta W_{2}$ 
by the amount $\lambda \tau \Pi\left(\beta, Q^{m}\right)$ and therefore shifts the schedule $\beta^{* *}(R)$. In addition, the creditors' utility $C_{2}$ is also reduced by the $\operatorname{tax} \tau \Pi\left(\beta, Q^{m}\right)$ in such situations. Creditors are therefore willing to lend a smaller amount of debt equal to the sum of the decrease in expected repayment and value of this tax. However, all in all, the corporate tax has no effect on the welfare evaluated at the debt level that entices lending from creditors. Formally, $\Delta V(\beta)$ is unchanged and the threshold cost $\widetilde{\beta}$ remains the same. The expected welfare is unchanged. Intuitively, the decrease in creditor utility and the welfare impact of a lower debt level acceptable by creditors are exactly balanced by the public gain from tax revenues.

Finally, note that the optimal repayment $\widetilde{R}$ is given by $\widetilde{\beta}=\beta^{* *}(\widetilde{R})$, which is independent of tax. Therefore, because $\beta^{* *}(R)$ falls in $R$, it must be that the introduction of the corporate tax diminishes the repayment level $\widetilde{R}$. Since the tax increases the ex-post incentives to default, the government reduces repayment levels to restore the same default likelihood. This naturally entices creditors to accept smaller debt levels; indeed, the maximum debt level that entices lending from

creditors decreases exactly by the amount $\Delta \widetilde{R} G(\widetilde{\beta})+\int_{\widetilde{\beta}}^{\bar{\beta}} \tau \Pi\left(\beta, Q^{m}\right) \mathrm{d} G(\beta)$ where $\Delta \widetilde{R}$ denotes the fall in repayment. To sum up, the introduction of a corporate tax decreases the debt and repayment levels. It does not affect the default policy and the expected welfare.

\section{Price cap}

In analogy to corporate taxes, the government can introduce a price cap to limit the creditors' profits when they get ownership of the firm. By the same token it will raise the consumer surplus when the state-owned firm is defaulted. However, a general study of the effect of a price cap raises additional issues. First, it requires a discussion about the firm's costs at which the price cap will bind or not and the costs at which the creditors may shut production. In the latter case, the creditors will certainly renegotiate the price cap with the government. Second, it raises the question of what the optimal price cap is. We do not intend to make such a detailed discussion here. However, as in Spiegel and Spulber (1994) and Cambini and Spiegel (2015), we can give insights by assuming an exogenous price cap that is high enough to avoid the threat of a production shutdown. This occurs for instance if the price cap is set equal to or higher than the highest cost under default.

In this case, the default production under the price cap is given by the schedule $Q^{c}(\beta)$ where $Q^{c}(\beta) \geq Q^{m}(\beta)$ for $\beta \geq \widetilde{\beta}$. Our previous analysis can then be replicated by replacing the laissezfaire output $Q^{m}(\beta)$ with this production schedule $Q^{c}(\beta)$. In particular the welfare difference functions $\Delta W_{2}$ and $\Delta V$ must now include $Q^{c}(\beta)$ instead of $Q^{m}(\beta)$ and are affected for cost parameters higher than the default threshold $\widetilde{\beta}$. We readily get the following neutrality result when the price 
cap binds only for some defaulted firms; that is, for those firms with the highest cost realizations. Then, the price cap does not bind for the defaulted firms with cost $\beta$ close to $\widetilde{\beta}$. Remember that the optimal cost and repayment level, $\widetilde{\beta}$ and $\widetilde{R}$, are given at the roots of the two functions $\Delta W_{2}$ and $\Delta V$. At the threshold $\beta=\widetilde{\beta}$, the production is given by $Q^{c}(\widetilde{\beta})=Q^{m}(\widetilde{\beta})$. As a result, the functions $\Delta W_{2}$ and $\Delta V$ do not change about $\beta=\widetilde{\beta}$ and $R=\widetilde{R}$ and thus accept exactly the same roots. So, we may conclude that the introduction of a price cap that binds only for some defaulted firms does not affect the government's default policy and its choice for the repayment level. The price cap however negatively affects the creditor's expected return from lending and entices them to lend a lower debt level. It also affects expected welfare because the price cap binds for defaulted firms with higher costs, which entices them to produce more, generate higher consumer surplus and decrease their profits.

When the price cap binds for all cost parameters of defaulted firms, the debt and repayment levels can unfortunately not be so easily predicted. ${ }^{32}$

\section{Private borrowing costs and time discounting}

Our model may be extended to account for the time discounting and the creditors' private cost of financing in the capital market. In this case, the creditors must repay $D(1+\rho)$ in the capital market in the second stage whereas the welfare rises by $(1+\lambda) D$ in the first stage. The creditors accept a debt up to the amount where $(1+\rho) D=R G\left(\beta^{* *}\right)+\int_{\beta^{* *}}^{\bar{\beta}} \Pi\left(\beta, Q^{m}\right) \mathrm{d} G$. Our results nevertheless remain the same when all parties are endowed with the same discount factor $\delta \in(0,1]$ and when the latter is related to the private cost of financing $\rho$ by the relationship $\delta=1 /(1+\rho)$.

To show this point, consider the case where repayments are low $(R<\underline{R})$,. Then, the expected welfare is equal to the constant $\mathcal{W}^{0}$ in expression (15) plus the following three terms: $(1+\lambda) D+$ $\delta[R-(1+\rho) D]-\delta(1+\lambda) R$. The first term expresses the government saving on equity injection in the first stage, which is valued at the shadow cost of public funds. The second term expresses the present value of creditors' utility, given their cash inflow from repayment and outflow to the capital market in the second stage. ${ }^{33}$ The last term represents the present value of the socially costly repayments as foregone revenues to the government in the second stage. In this case, the debt is always paid back and creditors accept the debt level such that $(1+\rho) D=R$. Then the three terms simplify to $-D(1+\lambda)[(1+\rho) \delta-1]$. When the discount factor is equal to $\delta=1 /(1+\rho)$,

\footnotetext{
${ }^{32}$ Since creditors expect less profits in the event of a liquidation, they will reduce their acceptable debt level. However, at the same time, the price cap raises the second stage welfare of all defaulted firms, including those with cost $\beta$ close to $\widehat{\beta}$, which incentivices the government to decrease $\beta^{* *}(R)$ and default the firm more often.

${ }^{33}$ Recall the creditors' utility in the first stage is $C_{1}=D-D=0$.
} 
this expression cancels out so that debt has no impact on the expected welfare. As a consequence, our previous analysis applies. However, the discount factor $\delta$ may be greater than $1 /(1+\rho)$ if the private cost of financing $\rho$ includes any additional feature such as transaction costs, capital market risk premium, etc. In this case the expected welfare falls with $D$ or equivalently with $R$. The repayment and debt are therefore avoided by the government because a too high capital market rate $\rho$ represents a leakage to the capital market.

For higher repayment levels $R \in[\underline{R}, \bar{R}]$, the expected welfare is computed as expression (16) plus the same term $-\widetilde{D}(R)(1+\lambda)[(1+\rho) \delta-1]$. Again when $\delta=1 /(1+\rho)$, this term cancels. Because $\Delta W_{2}$ and $\Delta V(\beta)$ are independent of $\rho$ and $\delta, \widetilde{\beta}$ and $\widetilde{R}$ do not change so that debt has no impact on the expected welfare. Again, our previous analysis applies. However, when $\delta>1 /(1+\rho)$, the too high private cost of financing represents a leakage to the capital market that the government wants to avoid. The government has therefore an incentive to reduce the value of debt and repayment as $\rho$ increases. For $\rho$ above but close to $(1-\delta) / \delta$, one can show that a rise in $\rho$ decreases the debt level. Figure 3 depicts the optimal debt for various private costs of financing, $\rho>0$, and for a discount factor, $\delta=1$. The picture is built using a model with linear demand and cost, $\Pi(\beta, Q)=(1-Q) Q-\beta Q$, and uniform distribution of cost parameter, $\beta \in[0,1 / 2]$. As expected, it shows that optimal debt levels increase with the shadow cost of public funds and fall with the private costs of financing.

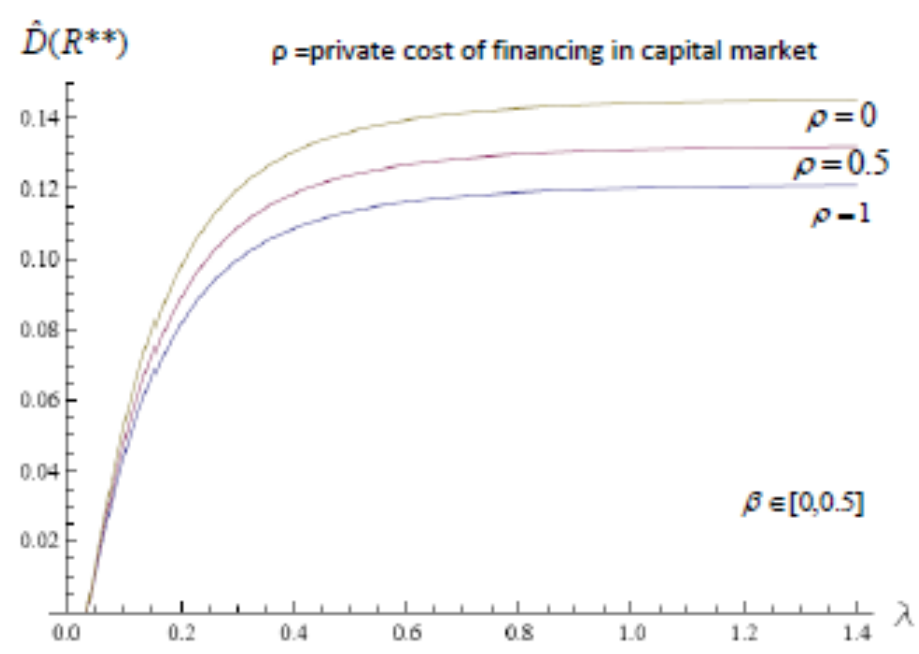

Figure 3: Debt vs social cost of public funds. 


\section{Foreign creditors}

In many countries the state-owned firms borrow from various domestic and foreign sources of funding. The presence of foreign creditors alters our analysis by the fact that the government is unlikely to consider their utility in its decision to default the firm. In this case, it accounts only for the utility of domestic creditors in its welfare evaluation. If we denote the share of domestic creditors by $\alpha \in[0,1]$, the welfare function must then include the terms $\alpha C_{1}$ and $\alpha C_{2}$ instead of $C_{1}$ and $C_{2}$. Interestingly, the presence of foreign creditors has no effect on the optimal debt level.

To see this, remember that the optimal repayment level is set to $\widetilde{R}=\Pi\left(\widetilde{\beta}, Q^{m}(\widetilde{\beta})\right)$ when all creditors were domestic (see (17)). At the cost and repayment level, $\widetilde{\beta}$ and $\widetilde{R}, \Delta W_{2}$ and $\Delta V$ are both equal to zero. Now consider the presence of foreign creditors, $\alpha<1$. It reduces the ex-post welfare of the state-owned firm $W_{2}^{0}$ by the utility of the foreign creditors, $(1-\alpha)(R-D)$, and it also reduces the default option $W_{2}^{1}$ by their utility level, $(1-\alpha)\left(\Pi\left(\beta, Q^{m}\right)-D\right)$. The welfare advantage of the state-owned firm $\Delta W_{2}$ therefore is increased by the difference between those utility levels, $(1-\alpha)\left(R-\Pi\left(\beta, Q^{m}\right)\right)$, which is exactly zero at $\beta=\widetilde{\beta}$ and $R=\widetilde{R}$. Hence, whereas $\Delta W_{2}$ is altered by $\alpha$, its root is unchanged. This means that the presence of foreign creditors does not change the government's default strategy. It can further be shown that the share of foreign creditors does not affect the difference $\Delta V$. As a consequence, repayment and debt levels are also unchanged. Intuitively, the government's default policy depends on the welfare assessment of the marginal state-owned firm with $\operatorname{cost} \beta=\widetilde{\beta}$. Since at this cost, creditors have the same utility under the two options, it makes no difference whether the government includes their utility in its welfare assessment.

\section{Bankruptcy and auditing cost}

In our model we have assumed that the creditors are able to obtain information about the firms at no cost at the default stage. We can briefly discuss the extension whereby creditors incur a fixed cost of audit or bankruptcy, $\phi$, when the firm is defaulted. This fixed cost captures the costs of management change, legal restructuring, creditors' coordination and/or information acquisition. To analyze this setting, we replace the profit after default $\Pi\left(\beta, Q^{l}\right)$ by $\Pi\left(\beta, Q^{l}\right)-\phi$. This fixed cost does not change output decisions but raises the welfare differences $\Delta W_{2}(\beta, R)$ and $\Delta V(\beta)$ respectively by $\phi$ and $(1+\lambda) \phi$. It thus raises both the default threshold $\beta^{* *}$ and $\widetilde{\beta}$. As a result, the public firm is less likely to be defaulted. The government simply avoids the payment of the above fixed cost. Does the government reduce the debt and repayment level with higher $\phi$ ? As mentioned earlier, the government sets the repayment level to the level of the 
profit of the marginal firm: $R^{* *}=\Pi\left(\beta^{* *}, Q^{m}\left(\beta^{* *}\right)\right)-\phi$, where the profit is now reduced by the fixed cost of audit or bankruptcy. ${ }^{34}$ Differentiating totally this expression, one gets $\mathrm{d} R^{* *} / \mathrm{d} \phi=$ $-1 /\left[1-\left(\mathrm{d} \beta^{* *} / \mathrm{d} R\right)\left(\mathrm{d} \Pi\left(\beta, Q^{m}\left(\beta^{* *}\right)\right) / \mathrm{d} \beta\right)\right]$. This expression will be negative when laissez-faire profits are not too sensitive to cost parameters and default thresholds not too sensitive to repayment levels. In this case, the government will reduce the firm's repayment level for all cost realizations. In addition creditors will accept lower debt levels because they get lower repayment levels and pay the additional fixed cost.

\footnotetext{
${ }^{34}$ At the equilibrium, we have $\beta^{* *}=\widehat{\beta}$ where $\Delta W_{2}\left(\beta^{* *}, R\right)=0$ and $\Delta V(\widehat{\beta})=0$. From those last two conditions, one gets $R=\Pi\left(\beta, Q^{l}(\beta)\right)-\phi$ evaluated at $\beta=\beta^{* *}=\widehat{\beta}$.
} 